\title{
Hizmet İşletmelerinde Kurumsal İmaj Bileşenleri; Sağlık İşletmeleri Üzerine Bir Araştırma \\ (Corporate Image Components in Service Enterprises; A Research on Health Enterprises)
}

\author{
Kadri Gökhan YILMAZ iD a Esat SAYGIN iD b Metehan TOLON iD c \\ a Ankara Hacı Bayram Veli Üniversitesi, İktisadi ve İdari Bilimler Fakültesi, İşletme Bölümü, Ankara, Türkiye. g.yilmaz@hbv.edu.tr \\ b Yüksek İhtisas Üniversitesi, Sağlık Hizmetleri Meslek Yüksekokulu, Tıbbi Tanıtım ve Pazarlama Bölümü, Ankara, Türkiye. \\ esatsaygin@yiu.edu.tr \\ c Ankara Hacı Bayram Veli Üniversitesi, İktisadi ve İdari Bilimler Fakültesi, İşletme Bölümü, Ankara, Türkiye. \\ metehan.tolon@hbv.edu.tr
}

\begin{tabular}{|c|c|}
\hline MAKALE BILLGİSİ & ÖZET \\
\hline $\begin{array}{l}\text { Anahtar Kelimeler: } \\
\text { İmaj }\end{array}$ & $\begin{array}{l}\text { Amaç - Bu çalışmanın amacı kurumsal imaj algı düzeyi ile kurumsal imaj faktörleri arasındaki ilişkiyi ve } \\
\text { etkiyi ortaya koymaktır. }\end{array}$ \\
\hline $\begin{array}{l}\text { Kurumsal İmaj } \\
\text { Kurumsal İmaj Faktörleri } \\
\text { Sağlik Hizmetleri } \\
\text { Hastane }\end{array}$ & $\begin{array}{l}\text { Yöntem - Çalışmanın verileri Ankara'da özel bir hastanede, yatan hasta birimindeki hastalardan } \\
\text { oluşmaktadır. } 213 \text { geçerli anket formu ile araştırmanın verileri analiz edilmiştir. Verilerin analiz edilmesi } \\
\text { için SPSS } 22.0 \text { istatistik paket programından yararlanılmıstır. Yapılan veri analizlerinde tanımlayıcı } \\
\text { istatistikler hesaplanmıştır. Kurumsal imaj algısı ile Kurumsal imaj faktörleri arasındaki ilişkiyi ortaya } \\
\text { koymak amacıyla korelasyon ve doğrusal regresyon analizleri yapılmıştır. Ortaya çıkan bulgular \% } 95 \\
\text { güven aralığında ve } \% 5 \text { anlamlılık düzeyinde incelenmiştir. }\end{array}$ \\
\hline $\begin{array}{l}\text { Gönderilme Tarihi } 2 \text { Temmuz } \\
2021 \\
\text { Revizyon Tarihi } 22 \text { Eylül } 2021 \\
\text { Kabul Tarihi } 26 \text { Eylül } 2021\end{array}$ & $\begin{array}{l}\text { Bulgular - Araştırmada kurumsal imajı oluşturan her bir boyut ile algılanan imaj arasında anlamlı ilişki } \\
\text { olduğu tespit edilmiştir ve imaj boyutları ile imaj algısı arasında kuvvetli bir ilişki olduğu görülmüştür. } \\
\text { İmaj algısının oluşmasında imaj faktörlerinin \% 50'lik bir etkiye sahip olduğu ortaya çıkmıstır. Algılanan } \\
\text { imaj üzerindeki en önemli faktörün iletişim boyutu olduğu dikkat çekmektedir. Buna karşın etkisi en } \\
\text { düşüuk boyutun ise sosyal faktörler olduğu söylenebilir. }\end{array}$ \\
\hline $\begin{array}{l}\text { Makale Kategorisi: } \\
\text { Araştırma Makalesi }\end{array}$ & $\begin{array}{l}\text { Tartışma - Araştırma sonucunda imaj algı düzeyi ile kurumsal imaj faktörleri arasındaki ilişki ve etki } \\
\text { ortaya koyularak sağlık kurumlarının olumlu kurumsal imaj yaratabilmeleri konusunda neler } \\
\text { yapabileceğine yönelik tavsiyelerde bulunulmuştur. }\end{array}$ \\
\hline
\end{tabular}

\begin{tabular}{l} 
ARTICLE INFO \\
\hline Keywords: \\
Image \\
Corporate Image \\
Corporate Image Factors \\
Health Services \\
Hospital
\end{tabular}

Received 2 July 2021 Revised 22 September 2021 Accepted 26 September 2021

Article Classification: Research Article

\section{ABSTRACT}

Purpose: The aim of this study is to reveal the relationship and effect between the level of corporate image perception and corporate image factors.

Design/methodology/approach - The data of the study consists of patients over the age of 18 who received service between 03.05.2021 and 04.06.2021 in a private hospital in Ankara, inpatient unit. The data of the research were analyzed with 213 valid questionnaires. SPSS 22.0 statistical package program was used to analyze the data. Descriptive statistics were calculated in the data analysis. Correlation and linear regression analyzes were performed to reveal the relationship between corporate image perception and corporate image factors. The resulting findings were analyzed at $95 \%$ confidence interval and $5 \%$ significance level.

Findings: In the research, it was determined that there is a significant relationship between each dimension that constitutes the corporate image and the perceived image, and it has been observed that there is a strong relationship between image dimensions and image perception. It has been revealed that image factors have a $50 \%$ effect on the formation of image perception. It is noteworthy that the most important factor on the perceived image is the communication dimension. On the other hand, it can be said that the least effect is social factors.

Discussion: As a result of the research, data were collected from external customers benefiting from the private hospital, and the relationship and effect between the level of corporate image perception and corporate image factors were revealed, and recommendations were made on what health institutions can do to create a positive corporate image. 


\section{GİRISS}

Kurumsal imaj, kurumun uzak veya yakın çevreye bakışını, vizyonunu, misyonunu, hedeflerini, politikalarını, hedef kitleye aktarır (Bal, 2012: 219). İmaj kavramı hem sosyal hayattaki bireyler hem de iş hayatındaki kurumlar için büyük önem taşımaktadır. Çünkü başarılı olmak isteyen kişi ve kurumlar olumlu bir imaja sahip olmalıdır. Örneğin, literatürdeki araştırmalar, kurumun imajı olumlu olduğunda müşteri sadakatinin de artma eğiliminde olduğunu ortaya koymaktadır. Böylece bireylerin bir kurumu algılama şekli olarak nitelenen kurumsal imaj, rekabette başarılı olmanın ana öğelerinden biri olarak kabul edilmektedir (Özata ve Sevinç, 2007: 59). Çünkü müşteriler bir markaya karar verirken kurumsal imaj1 değerlendirmektedirler. Bu, günümüzün rekabetçi pazarlarında müşterilerin imaj ve itibar gibi hususları daha çok önemsediğini göstermektedir. Daha iyi kurumsal imaj yeni müşterilerin tercihinde etkili olduğu gibi mevcut müşteriler ile de sürdürülebilir ilişkiler bakımından önem taşımaktadır. Kurumlar artık daha iyi bir kurumsal imaj ve itibar geliştirmek için rekabet ediyorlar (Adah,2020:76).

Anderson ve Sullivan (1990) mevcut bir müşteriyi elde tutmaktan ziyade bir müşterinin rakipten geçiş yapması için daha fazla mal ya da hizmet iyileştirmesi gerekliliğini ortaya koymuştur. Bir müşterinin ilişkisinin uzun ömürlü olması karlılı̆̆ı olumlu yönde etkiler. Mal ya da hizmetten memnun oldukları için bir firmada yıllarca kalan müşteriler, kısa vadeli müşterilere göre ek hizmetler satın alma ve ağızdan ağıza daha uygun iletişim yayma olasılıkları yüksektir. Bu durum da olumlu imajı güclendirecektir. Ayrıca kurum rakiplerinden daha yüksek bir fiyatlandırma yapabilir, çünkü bu müşteriler bildikleri kurum ile ilişkiyi sürdürmeye değer verir. Mevcut müşterileri çekmenin ve ilişki kurmanın ilk maliyetleri de zaten harcanmıştır ve genellikle onlara daha verimli bir şekilde hizmet verilebilir. Rose (1990) on yıllık bir müşteri tarafından satın alınan kredi kartı hizmetlerinden elde edilen kârın beş yıllık bir müşteriden ortalama üç kat daha fazla olduğunu iddia ederek bu görüşü desteklemiştir. Mevcut müşterileri elde tutma bakımından da uzun dönemli kurumsal imaj yönetiminin önemli olduğunu söyleyebiliriz (Zeithaml, Berry ve Parasuraman, 1996: 33).

Kurumsal imaj, bir kurumun mimarisi, adı, gelenekleri, ideolojisi, çıktı çeşitliliği ve kurumun müşterileri ile etkileşiminde girdi olabilecek çeşitli fiziksel ve davranışsal niteliklerin hepsi ile beraber kalitenin algılanışı ile ilgilidir (Çiçek ve Almalı, 2020: 223). Kurumsal imaj oluşturulurken öncelikli amaç, mevcut ve potansiyel müşterilerin kuruma karşı olumlu bir tutum içerisinde olmalarını sağlamaktır. Kurumsal imaj, pozitif bir kurumsal kimlik, pazarlama iletişimi ve kanallarına ek olarak hedef kitleden elde edilen geri bildirimlerden oluşur (Virvilaite ve Daubaraite, 2011: 536)

Kurumlar, paydaşlarına doğru ve güçlü bir imaj yansıtarak olumlu geri bildirim almak isterler. Çünkü olumlu bir kurumsal imaj, kurumun faaliyetlerinin sürekliliği ve stratejik başarısı için ihtiyaç haline gelmiştir. Pazarlama alanının belirli mal ya da hizmet için olumlu bir imaj yaratma gayretlerinin ötesinde, olumlu ve güçlü kurumsal imaj, ürünlerin satışını artıran bir motivasyon kaynağıdır (Erdoğan, Develioğlu, Gönüllüoğlu ve Özkaya, 2006:56). İyi bir kurumsal imaj, kurumlar için rekabet avantaji sağlar. Müşterileri çekmek, elde tutmak ve büyütmek için bir şirketin güçlü bir kurumsal imaja sahip olması gerekir (Adah, 2020: 77). Aksi taktirde paydaşlar kurum ya da ürünleri ile ilgili olumsuz bir algı edinirlerse, satışları ve karları kesinlikle azalacaktır (Gray ve Balmer, 1998:697).

Paydaşlar şirketin imaj oluşturma eylemlerinden etkilenir ve çevreleri ile kurumsal imaj oluştururlar. Kurumsal İmaj, şirketin planlanan ve tesadüfi faaliyetlerinden etkilenir (Virvilaite ve Daubaraite, 2011:536). Çoğu büyük şirketin ilgilenmesi gereken ana paydaşlar şunlardır: müşteriler, distribütörler ve perakendeciler, tedarikçiler, girişim ortakları, finans kurumları ve analistler, hissedarlar, devletin düzenleyici kurumları, sosyal eylem kuruluşları, genel kamu ve çalışanlar (Gray ve Balmer, 1998:697). Bu paydaşların gözündeki kurumun imajı, kuruma destek sağlayıp sağlamayacaklarını,beklentilerini ve görüşlerini etkileyecektir. Bu nedenle, kurum olumlu kurumsal imajından dolayı nitelikli personelleri çalıştırabilir. Sadece çalışanları değil, aynı zamanda başarı için ihtiyaç duyulabilecek analistleri, yatırımcıları, müşterileri ve ortakları da kendisine çekebilir (Erdoğan, vd. 2006: 56). Ayrıca olumlu imaja sahip kurumlar sermaye piyasalarına erişimlerini artırarak itibar gücü için de aktif olarak rekabet edebilirler (Furman, 2010:69)

Kurumsal imaj, iyi tasarlanmış iletişim programları aracılığıyla daha hızlı şekillendirilebilir. Kurumun ve sektörün dinamiklerine göre değişmekle birlikte, iyi çıktılar üretebilmek, iyi yönetim yapısına sahip olmak, toplumu yansıtabilmek, müşterilerin ihtiyaçlarını gidererek tatmin duygusu uyandırabilmek ve insanların çalışmayı arzulayacağı bir kuruluş olabilmek imajın temel belirleyicileri olarak ifade edilmektedir (Javalgi vd., 


\section{K. G. Yilmaz - E. Saygin - M. Tolon 13/3 (2021) 2780-2799}

1994; akt. Çiçek ve Almalı, 2020: 223). Olumlu kurumsal imaj, buluşlar ve yenilikler (sadece ürün yenilikleri değil, süreçlerdeki yenilikler, organizasyon yapısı, yönetim vb.) ile kalite, iletişim, ticari satış vb. gibi fiyat dışı rekabet unsurlarında da avantaj sağlar (Małová, Dzian, Triznová,Paluš ve Parobek, 2015: 226). Ortaya çıkan güçlü kurumsal imaj kurumlara duygusal olarak katma değer katar, algılanan kaliteyi etkileyerek müşteri memnuniyeti üzerinde önemli bir role sahip olur, kendisini farklı ve güvenilir kılarak rakiplerinden önde olmalarını sağlar (Erdoğan, vd. 2006:57) İyi bir imaja sahip kurumlar, hedef kitlenin üzerinde saygın, güvenilir, işbirlikçi ve gelecek vaat eden bir kuruluş imajı oluşturur. Bundan dolayı kurumların faaliyet alanları ne olursa olsun olumlu bir imaj oluşturmaları ve kalıcı hale getirmeleri büyük önem taşımaktadır (Özata ve Sevinç, 2007:60). Özellikle hizmet üreten kurumlar için hizmet unsurunun soyut olması, üretiminin ve tüketiminin eş zamanalı olması, sahipliğinin olmaması depolanamaması, hetorojen yapıda olması gibi özellikler (Öztürk, 2016: 17) de göz önüne alındığında kurumsal imajlarını yönetmelerinin daha da zorlaşabileceği öngörülebilir.

Ayrıca üretilen hizmet kapsamının insan sağlığı olmasından dolayı sağlık sektöründe imajın yönetiminin diğer kurumlar ile kıyaslandığında daha zor ve önemli olduğu görülmektedir. Günümüzdeki şartlarda rekabet gücünü arttırabilmek amacıyla sağlık kurumu yöneticilerinin, olumlu kurumsal imaj ortaya çıkarmak ve sağlık hizmeti tüketicilerinin memnuniyetini arttırmak için etkili stratejiler geliştirmeleri oldukça önemlidir (Güngör, Şahin ve Bayram, 2020: 310)

Sağlık sektörü, rekabetin yoğun olduğu sektörlerden biridir; Özellikle son zamanlarda devlet hastanelerinin yükselen kalitesi, üniversite hastanelerinin yatak ve poliklinik kapasitelerindeki artışı ve çok sayıda özel sağlık kuruluşunun faaliyete geçmesi sektördeki rekabeti hızlandırmıştır (Deniz ve Yüksel, 2018:928). Her ne kadar karşılanamayan sağlık hizmetleri önemli bir sağlık sistemi unsuru olsa da (Başar vd., 2021: 787, Dikmen ve Dikmen, 2020: 539), özel sektördeki hastane sayısının artması ve sigortalıların bu hastanelere sevk edilerek ücretsiz tedavi görme imkânı da sektörde hareketlilik yaratmıştır. Sağlık hizmeti tüketicilerinin tercihte bulunurken dikkate aldıkları faktörler ile ilgili olarak hastaneler üzerinde çalışmalar yapılması ve hastanelerin de bu çalışmaların sonuçları doğrultusunda kurumsal imaj bileşenlerine dikkat etmesi sonucunda sürdürülebilirlilikleri sağlanacaktır (Bal, 2012: 220).

Sonuç olarak yüksek temas hizmetler içerisinde yer alan sağlık hizmetini üreten işletmeler ve kurumlar açısından da kurumsal imaj hayati öneme sahiptir. Zira hammaddesi insan olan bu hizmet grubunda iç ve dış müşteri memnuniyeti, sadakat, rekabet üstünlüğü, kalite gibi önemli birçok unsur kurumsal imajla ilişkilidir. Bu bağlama çalışma kapsamında kapsayıcılığı ve etkileşimi yüksek olan kurumsal imaj kavram ve olgusunun sağlik sektöründe incelenmesi amaçlanmıştır.

\section{KAVRAMSAL ÇERÇEVE}

\subsection{Kurumsal İmaj}

İmaj kavramı, insanların, kurumların veya malların ve hizmetlerin olumlu veya olumsuz yönlerini ifade etmek amacıyla günlük dilde kullanılan bir kavramdır (Özata ve Sevinç, 2007:59). İmaj; Bir planla birlikte ya da plansız bireye gönderilen mesajlar ile birlikte kuruluşun karmaşık, çok yönlü bir sürece ve sosyal, tarihsel ve fiziksel faktörlere ayrıca kazanılmış bireysel deneyimlere tabi tutulması neticesinde ortaya çıar. Başka bir ifade ile, imaj kişi ya da kurumların kasıtlı ya da kasıtsız olarak birbirlerine bıraktıkları izlenimidir (Erdoğan vd, 2006:56). İnsanların tanımladıkları, hatırladıkları ve bağ kurdukları kurumun bütün algısı kurumsal imaj olarak açıklanır. "Paydaşlar kurum hakkında ne düşünüyor? Biz hakkımızda nasıl düşünmelerini arzuluyoruz? " şeklindeki sorular yöneticilere sorulansa en stratejik sorular arasındadır. Kurumsal imaj kavramı bu soruların arkasında yatmaktadır (Sypropoulou ve Diğ., 2010, s.753 aktaran Önder ve Bayın, 2014: 122). Bir kuruma ilişkin imaj kavramının ilk olarak 1955 yılında Sidney Levy tarafından kullanıldığı ifade edilmektedir. Levy'nin ortaya koyduğu fikir, hedef kitlenin sadece fiziksel özellikleri ve işlevleri için değil, aynı zamanda anlamları için de bir ürün veya hizmet satın alması şeklindedir (Levy, 1999: 233 aktaran Uluçay, 2018:19).

Kurumsal imaj bir proses biçiminde açiklandığında, kurumun takdim etmeye veya göstermeye uğraştığı imajın tüketicilerin ondan aldığı mesajlarla ilişkili olduğunu söylemek mümkündür. Başka bir ifadeyle, hedef kitlelerin aklında kurumun kimliğine dayatılan sıfatla ilgili bir dizi yargıdır (Aksoy ve Bayramoğlu, 2007:8687). Kurumsal imaj, kurumsal kimlik gösterimlerinin hedef kitle için ortaya koyduğu bütünsel algidır ve en 
düşük birimden en yüksek birime kadar tüm güçlerin birleşiminden oluşur. Kurumsal imaj bir örgütün gerçekliğinin yansımasıdır. Kurumun paydaşları tarafından nasıl algılandığıyla da yakından ilişkilidir (Erdoğan vd, 2006: 56). Görülebileceği gibi, Sydney Levy kurumsal imaj kavramını 1955 yılında literatüre tanıttıktan sonra, bu kavram başka birçok şekilde yeniden yorumlanmıştır (Uluçay, 2018: 19).

\subsection{Kurumsal İmajın Özellikleri}

Kurumsal imajla ilişkili tanımlara bakıldığında birtakım özellikler ön plana çıkıyor. İlk olarak, kurumsal imajın fiziksel bir öğe olmadığı görülmektedir. Başka bir özellik ise kurumsal imajın akılcı ve duygusal bağlılıkla oluşturulmasıdır. Üçüncü özellik, kurumla ilgili algıların, hedef kitleyi oluşturanların zihninde zaten var olduğudur (Bakan, 2005: 37 aktaran Önder ve Bayın, 2014: 122). Bu özelliklere bakıldığında üç genelleme göze çarpmaktadır. Birincisi, kurumsal imajın paydaşların zihnindeki izlenimlerden oluşmasıdır. Buradan da kurumsal imajın somut unsurlardan oluşan soyut bir kavram olduğu anlaşılmalıdır. İkinci genelleme, farklı grupların zihinlerinde farklı imgeler oluşturulabilmesidir. Bu noktada, tüm paydaşların kurumsal imajın oluşmasında aktif rol oynadığı söylenebilir. İfade edilebilecek son genelleme, kurumsal imajin bütüncül anlayışıyla diğer bir deyişle kurumu ilgilendiren tüm parametreleri göz önünde bulundurarak incelemek gerekliliğidir (Uluçay, 2018:19).

İyi planlanmış bir kurumsal imaj stratejisi, kurumun kendisini diğer kurumlardan ayırt etmesine ve pozitif bir itibar sağlamasına destek olur. İyi bir imajın itibar ile etkileşimi, müşteri sadakatinin gelişmesini sağlar. Rekabetin hızla arttığı ve sınırların kaybolduğu global iş dünyasında, bu unsurlar çok iyi yönetilmesi gereken kavramlar olarak karşımıza çıkmaktadır ve ayrıca üst yönetimin görevleri arasındadır(Erdoğan ve Gönüllüoğlu, 2006:49-50 aktaran Emül ve Naldöken, 2019: 362).

\subsection{Kurumsal İmaj ve Sağlık Sektörü}

İmaj algısı her daim nesnesi veya kaynağıyla tam olarak eşleşmeyebilir (Gruning ve Repper, 2005:77 aktaran Çetin ve Tekiner, 2015:420 ). Bir kurumun iletmek istediği mesaj farklı bireyler ve gruplar tarafından farklı algılanabilir (Çerik ve Erkmen, 2006). Bununla birlikte, genel olarak, toplumda anlaşılanın imaj olduğu bilinmelidir. Başka bir deyişle algılanan, gerçeği yansıtır (Çetin ve Tekiner, 2015: 420). Bundan dolayı kurum, bir imaj oluştururken rakiplerin ve çevrenin beklentilerini gözlemlemeli ve kendi kimliğiyle uyumunu sağlamalıdır (Çerik ve Erkmen, 2006). Farklı hedef gruplar, kurumlarca sunulan imgeler ve kurumsal imajın yansımaları hakkındaki bilgileri farklı şekillerde yorumlar ve bir muhakeme yapar (Bayramoğlu, 2007:18).

Günümüz toplumlarında, kurumlar, küreselleşmenin ve büyük değişikliklerin olduğu ortamlarda rekabetçi, güçlü ve farklı bir imaj yaratmalıdır (Çerik ve Erkmen, 2006). Bu nedenle, hedef grubun kurum hakkındaki tüm algısını gösteren kurumsal imaj, kısmen bu hedef grubun çıarlarını ve gereksinimlerini karşılama becerisine dayanmaktadır (Bayramoğlu, 2007: 18). Güçlü bir kurumsal imaj, iyi bir imaj yönetimi gerektirir. Kurumlar, tüm ürün, marka, şirket, endüstri, ülke ve kullanıcı imajlarını bir bütün olarak yönetirlerse başarılı olurlar (Çerik ve Erkmen, 2006). Başka bir deyişle, bir kurumun farklı paydaşların gözünde farklı imajlara sahip olması mümkündür. Kurumsal iletişim birimleri, farklı paydaşların ihtiyaçlarını ve tutumlarını anlamak için araştırma yapar ve kurumlarının imajını güçlendirmek için bu paydaşlarla daha iyi iletişim kurma çabası yürütürler (Erdoğan vd, 2006:56). Bu açıdan kurumun hedef kitlesi üzerinde oluşan güçlü zayıf modern güvenilir kaliteli vb gibi etkiler, imajı oluşturduğu düşünülen tüm pozitif ve / veya negatif tanımlar olarak görülmektedir. Kurumsal imajı ortaya çıkarmak için, kurumun iç ve dış çevreye en iyi şekilde açıklanabilecek imajı belirlemeye yönelik araştırma yapılması gerektiği düşünülmektedir (Çetin ve Tekiner, 2015:420). Dolayısıyla literatürde bu yönde araştırmalar yoğunlukta olmasına rağmen hastaneler üzerinde çok sayıda kurumsal imaj çalışmasının olmadığı görülmektedir. Kurumsal imaj çalışmaları, bir hizmet kurumunun ötesinde bir işletme olarak toplumun ve hastanelerin değişen beklentilerinin bir sonucu olarak önem kazanmıştır. Kurumsal imaj önem kazanırken, başta hastaneler olmak üzere sağlık hizmeti veren kurumlar hizmet ve imajlarını geliştirmek için faaliyetler yürütmeye başlamışlardır (Emül ve Naldöken, 2019:362).

Bütün sektörlerdeki gibi sağlık sektöründe ve hastane işletmelerinde de rekabet vardır. Rekabetin olduğu sektörlerde başarılı olmanın ana koşulu, müşterileri memnun etmek ve müşterilerin sürekliliğini sağlamaktır. Hastanelerin bunu yapabilmek amaciyla pozitif bir kurumsal imaj yaratması zorunludur. Aksi takdirde, müşteriler diğer kurumlara yönlendirileceğinden hastanelerde kurumsal bir imaj yaratmaya çalışmak yaşamsal önem taşıyacaktır (Kanoğlu,2016:24). 


\section{K. G. Yilmaz - E. Saygin - M. Tolon 13/3 (2021) 2780-2799}

İnsan yaşamı sağlık kavramı etrafında şekillenmiştir. Toplumun ve bireylerin hayatını yönlendiren önemli faktörlerden biri de sağlık olgusudur (Ayten ve Zağlı,2019:104). İnsan yaşamının sürdürülmesinde, belirli bir yaşam kalitesinin tesis edilmesinde ve korunmasında sağlık ve sağllk hizmet sunumunun özel bir önemi vardır. Sağlık personelinin hasta ve yakınları ile iletişimi, hasta ve hasta yakınlarının kullandıkları sağlık hizmetlerinin kalitesi ve yeterliliği sonucundaki müşteri memnuniyeti düzeyinin kurumun imajına önemli derecede etkisi olacaktır (Ayten ve Zağl1,2019:101). Geçmiş yıllarda sağlik kuruluşlarının müşterileri dendiğinde genellikle ilk akla gelen hastalar olmaktadır, ancak günümüzde sağlık hizmetlerinin üretim sürecine dahil olan tüm kişi ve kurumlar sağlık müşterisi / paydaşları haline gelmiştir (H.Hoşgör, Memiş, D.Hoşgör, Tütüncü, 2017:442). Müşterilerin birçok farklı unsuru dikkate alarak değerlendirme yapmalarından dolayı rekabet halindeki sağlık kuruluşlarının kurumsal imajlarında da çok çeşitlilik vardır. Bu nedenle başarılı imaj yönetimi için müşterilerin kurum ile ilişkilendirdikleri bileşenlerin anlaşılması ve incelenmesi önemlidir.

Kurumsal imaj, hastaların bir sağlık kuruluşu ile ilgili düşünce, inanç ve izlenimlerinin toplamı olarak açıklanabilir (Önder ve Bayın, 2014:122). Kısa vadeli fonksiyonel faydalarından ziyade uzun vadeli imajı güçlendirmek için hizmet kalitesi ve müşteri memnuniyeti oluşturulmalıdır. Birçok çalışma, sunulan hizmet kalitesinin ve müşteri memnuniyetinin kurum imajı üzerinde pozitif bir etkiye sahip olduğunu göstermiştir. Kaliteli hizmet sunumu ile hastaneler hasta memnuniyeti ile olumlu bir kurumsal imaj ortaya çıkartılabilir (Derin ve Demirel, 2010: 166).

Kurumsal imaj oluşumunda izlenecek faaliyetleri aşağıdaki gibi sıralayabiliriz (Özalkuş, 1994: 153 aktaran Taşkın ve Sönmez, 2005: 2):

- Var olan imajın güçlü ve zayıf yönleri ortaya çıkarılmalıdır. Böylelikle geçerli iş yapma fırsatı ortaya çıkar ve kurumsal imaj hakkında müşteri kitlesinin ilgilendiği sorular ortaya çıar.

- Var olan durum tespit edildikten sonra kurum adına alınacak aksiyonlar, zayıf yönleri güçlendirecek tedbirleri içerecek şekilde planlanmalıdır. Bu adımda SWOT analizi yapılmalıdır ve "Biz kimiz? Neden bu buradayız?" gibi soruların da cevaplanması gerekir.

- İstenilen imajı hedef kitleye aktarabilecek hususlar ortaya konulmalıdır. Burada önemli olan, tüm listeyi ve amacı anlaşılabilecek basit, az sayıda terime indirgemektir. Hedef kitle sürekli olarak birçok mesaja maruz kaldığı için, istenilen mesajların aktarılması hedef kitle ile kurum arasında kurulan bağın gücüne bağlıdır.

- İmaj oluşturmak için bütün araçlardan yararlanılmalıdır. Çünkü imaj bağlantı kanallarının (reklam, ürün, çalışanlar, bayiler vb) artmasıyla ve doğru kullanılması ile istenilen imaj oluşumunun gücü ve hızı da artar.

\subsection{Kurumsal İmajın Bileşenleri}

Bu çalışmada, kurumsal imajı etkileyen faktörler literatür analiz edilerek 4 başlık şeklinde incelenmiştir. Schukies (1998)'e göre; bu faktörler; fiziksel faktörler, sosyal sorumluluk faktörleri, iletişim faktörleri ve kalite faktörleridir (Bayın ve Önder, 2012:143).

\section{$\checkmark$ Sağlık Kurumlarında Fiziksel Faktörler:}

Kurumların fiziksel özelliklerinin imaj oluşumu ve mevcut imajının devamlılığı üzerinde etkisi olduğu bilinmektedir. Fiziksel faktörler, özellikle görselliği vurgulayarak pozitif bir kurumsal imaj yaratmak arzusundaki kuruluşlarca göz ardı edilmemesi gereken hassas bir faktördür. Bu nedenle kuruluşlar, istedikleri imajı yaratmak için tüm birimlerinde, hem mekan hem de insanlar için fiziksel yapıları ayrıntılı olarak tasarlamalıdır (Çalışır, 2019:43).

Bir kurumun fiziksel faktörlerinden bahsedildiğinde, binanın iç ve dış mimari tasarımı, temizlik ve peyzaj, çalışanların elbiseleri, logo, kurumun renkleri, yazı tipi, simge, her türlü basılı malzeme, ambalaj, satış kalkınma önlemleri, reklamlar, sergiler ve standlar, çevre gibi fiziksel faktörler, binaların dış görünüşleri, varsa bina çevresindeki arazi ve ofislerin görünümü ve resepsiyon alanı akla geliyor. Burada özellikle ilgi çekici olan renk tasarımı, aydınlatma, mobilya, bakım, süreklilik, temizlik, tasarım ve estetiktir. Bugün, bu fiziksel faktörler sadece tasarlanmakla kalmıyor, aynı zamanda yönetilmesi de gerekiyor (Emül ve Naldöken, 2019:362). Bu yönetim süreci içerisinde, özellikle müşterilerin değerlendirme yapmalarının kolay olmadığ1 soyutluk boyutu yüksek olan sektörlerde fiziksel faktörler daha da kritik bir öneme sahiptir. Örneğin sağlık 
sektöründe hizmet alımında bulunacak hastalara sunum gerçekleştirilirken fiziksel unsurların, hizmet tasarımında mutlaka dikkate alınması gerekmektedir (Altunışık, 2015: 183). Çünkü hastaya sunulan sağlık hizmeti, sağlık personeli tarafından gerçekleştirilen bir uygulama ve faaliyettir. Hastanın görebileceği hizmetin fiziksel faktörleri (hastane odası, ekipman vb.) olmasına rağmen asıl hizmet görülemez ve dokunulamazdır ( Yükselen, 2013: 414).

Müşterilerin satın almadan önce kurumun kalitesini değerlendirmek için işletme ile iletişimde bulunduğu ilk durumlarda da işletmeler hizmeti görünür hale getirmelidir. Nitekim sağlık kuruluşlarının fiziksel ve çevresel nitelikleri, hasta memnuniyetini etkileyen önemli bir unsurdur. Bunlar aydınlatma, temizlik, gürültü, 1sı, havalandırma, otopark imkanı, bekleme odaları, dış görünüm vb özellikleri içermektedir (Kavuncubaşı ve Yıldırım, 2015: 486). Ayrıca dikkate alınması gereken bir diğer uygulama da, yapı oluşturulurken müşterilerin hoşuna gidecek şekilde ışıklandırma, 1sıtma, renklendirme, ses ve müzik, koku gibi hizmet ortamında yer alan unsurların, insanlara olumlu psikolojik girdi verecek şekilde düzenlenmesidir. Çalışmalar göstermiştir ki bu düzenlemelerin hizmetin satın alınması konusunda müşteriler üzerinde önemli etkisi vardır (Tengilimoğlu, 2016: 336).

Benzer şekilde kurumun hastalara ulaştığı mecralardan birisi olan reklamlarında, odaların genişliği, kullanılan yeni malzemeler, hastane personelinin uzmanlığı ve güler yüzlü olduğu vurgulanabilir. Bu nedenle hizmet kurumunun amacı soyutluğa fiziksel kanıt ve hayal gücü eklemek ve soyut durumu somutlaştırmaktır (Süer, 2014: 200). Hastanedeki doktor odasında yer alan bilimsel çalışma ve başarı ödülleri kitaplığının kitaplarla dolu olması vb hizmet kalitesini göstermeye yönelik fiziksel kanıtlardır (Erdoğan, 2014: 346).

Neticede kurum hakkındaki izlenimler ile birlikte genel görünümü de kurumsal imajı büyük ölçüde etkilemektedir. Çünkü kurum ortamının ve bekleme yerlerinin düzeni vb. binanın fiziksel unsurları mesaj kaynağı olarak kabul edilir. Bu unsurlar kurumun kendisini nasıl ifade ettiği ve kendini nasıl ifade etmek istediği ile ilgilidir (Aras, 2019: 44). Bu nedenle hastanelerde bekleme salonundaki koltukların okul sırasına benzer şekilde yan yana dizilmemesi gerekmektedir. Ek olarak fiziksel bileşenler ile ilgili olarak ele alınabilecek başka bir konu da hizmetin üretiminde yararlanılan tıbbi teknoloji, laboratuvardaki cihazlar, rontgen cihazları hasta yatağı vb gibi kullanılacak materyallerin son teknolojiye uygun ve birbirleri ile uyumlu olması önemlidir (Tengilimoğlu, 2016:301).

Sağlık sektöründe fiziksel faktörler konusundaki araştırmaların çoğu hastanelerin fiziksel faktörlerinin hastalar ile ilişkisi üzerine odaklanmıştır. Sonuç olarak ise hastane odalarının temizliği genişliği düzeni pencereleri manzarası ve mahremiyeti gibi özellikler hasta memnuniyetinde olumlu sonuçlar ortaya koymuştur. Bunların yanı sıra hastanenin fiziksel tasarımının personel üzerindeki etkisini inceleyen çalışma sayısı az olmasına rağmen mevcut literatür, sağlık hizmeti ortamlarının personelin sağlık ve güvenliğini etkilediğini ve çalışma alanlarının iyileştirilmesinin personelin de etkililiğini ve memnuniyetini artırabileceğini ve hataları azaltabileceğini göstermektedir (Parish, Berry ve Lam, 2008: 222).

Sonuç olarak kurumların fiziksel özellikleri hem bir imaj yaratma prosesinde hem de mevcut imajı korumada çok önemlidir. Bu, kurumların iç dekorasyonundan ürünlerinin fiziksel özelliklerine kadar ayrıca markalar, yazı ve basım şekilleri, renk seçimi, mimari tasarım, müşteri yayınları, oryantasyon programları, kurum içi yayınlar, bilgi ve iletişim gereçleri, eğitim materyalleri, işyeri, makine ve ekipmanları, oda ve mekan düzenlemeleri gibi belirli bir programdaki birçok fiziksel öğenin değerlendirilmesini zorunlu kılar. Bunlar kurumsal bakış açısı çerçevesinde değerlendirilir. Kurumsal görünüm sadece kurumsal renklerin, desenlerin ve her şeyin tasarımını değil, aynı zamanda personelin giysileri, kurumun binalarının kapılarının yemek salonunun görünümünü, kullanılan materyallerin nasıl görüneceği ve hatta şekli gibi kurumun görünümünü etkileyen hassas detayları da kapsar (Semerci,2016:26).

\section{$\checkmark$ Sağlık Kurumlarında Sosyal Sorumluluk Faktörü:}

Sosyal sorumluluk, işletmelerin nihai kararı vermeden önce, alacakları kararların toplum üzerindeki etkilerine kapsamlı bir şekilde yansımasını düşünerek karar alması ve ardından harekete geçmesidir. İşletmeler toplum ile yaşamak zorundadır. Bundan dolayı kendilerinden başka birey ve kurumlarla sosyal ilişkiler kurmak ve bu ilişkileri güçlendirerek sürdürmekle yükümlüdürler. İş dünyasında faaliyette bulunan kuruluşların örgütsel davranışlarından sorumlu olmanın yanı sıra topluma karşı da mesuliyetleri vardır (Çalışır, 2019:44). Küreselleşmenin etkisiyle yoğun bilgi karmaşıklı̆̆ı ile karşılaşan tercihlerinde karar vermede zorlanan 


\section{K. G. Y1lmaz - E. Saygin - M. Tolon 13/3 (2021) 2780-2799}

müşterilerin davranışlarında duygu ve tecrübeler ön plana çıkmaya başlamıştır. Sosyal sorumluluk bilincinin arttığ günümüz dünyasında; sağlam, sürdürülebilir ve güçlü bir kurumsal imaj oluşturmak için sosyal olarak sorumlu bir kurum olmayı gerektirmektedir. Sosyal sorumluluk bilinci olan kurumlar, hem kurumsal personel hem de paydaşlar tarafından saygı ve takdirle anılan güvenilir kuruluşlar olarak algılanacaklardır (Ural, 2000 :411-416). Kurumlar, kamuoyunun güvenilir, dürüst ve sosyal sorumluluğunu yerine getiren bir kurum izlenimi oluşturmuşlarsa, kriz zamanlarında toplumu ve devleti destekçi olarak yanında bulmaları ile krizden kurtulma şanslarını arttıracaklardır (Kanoğlu, 2016:10-21-22). Sosyal sorumluluk bilincine sahip kurumlar, çalışanlarından tüketicilerine saygı duyulan ve güvenilen kurumlar olarak bilinecektir. Kâr dışında, sosyal sorumluluk kavramı da kurumların hayatlarına daha fazla devam etmeleri için de önemlidir. Sosyal sorumluluk, kurumların çevrelerine duyarlı olmalarını savunur ve özel kurumlar için çok önemli bir konu haline gelmiştir. Hayırseverlik faaliyetleri ile çevreye duyarlı ve müşteri üzerinde sosyal sorumluluğu olan şirketler olumlu bir şirket imaji elde edebilirler (Aras, 2019:48). Kurumlar, toplumu düşünmeden, kısa vadede, yalnızca kârlılığa yönelik planlar ile faaliyet gösterirlerse uzun süreçte istenen hedeflere ulaşmanın mümkün olmadığını görmüşlerdir. Bunların farkında olan bilinçli kurumlar, sosyal sorumluluk sahibi olduklarını gösteren projeleriyle toplumun karşısına çıkmaktadır (Kanoğlu, 2016:21). Bu nedenlerle, bir kurumdaki profesyonel imajin, sosyal alanlarda üstlendiği roller ve sergilediği sosyal sorumluluk hassasiyeti; müşteriler üzerinde, üretilen mal ve hizmetlerin yarattığı duygusal ve estetik etkiye ek olarak olumlu ya da olumsuz kurumsal imaj yaratılmasında büyük rol oynamaktadır (Gülseven,2019:64).

Çok sayıda çalışma etiği araştırmaları, kurumların faaliyetlerinde taşıdığı sorumluluğun anlamı üzerine tartışmalara odaklanmıştır. Sosyal sistem üzerindeki etkisi ile ilgili olan sosyal sorumluluk, kurumun toplumun nezdindeki imajıyla paralel seyretmektedir. Toplum, daha çok para kazanan kurumu değil sosyal sorumluluğu olan kurumları sever (Çalışır, 2019:44). Çünkü bugün müşteriler bir mal ya da hizmeti sadece mali değeri ve kalitesiyle değil, aynı zamanda onu üreten kurumların sosyal sorumluluk faaliyetlerinin de farkında olarak seçim yapmaktadır. Sosyal sorumluluk faaliyetleriyle sosyal haysiyet kazanmanın etkisiyle, kurumların imajına değer katılmakta ve bu durumda kurumun marka değerine etki etmektedir (Aktan ve Börü,2007:19- 20)

Sağlık sektöründe, diğer sektörlere nazaran daha fazla çevresel zorluklar söz konusudur.( Bayın ve Akbulut, 2012:57) Sosyal sorumluluk kapsamında sağlık sektörünün ana hedefi; ihtiyaca uygun olarak toplumun tüm üyelerine uygun, eşit, kaliteli, ucuz, erişilebilir ve yeterli düzeyde hizmetlerini sunmaktır. Mümkün olduğu kadar coğrafi, sosyal, finansal imkan ve unsurlarla sınırlı olmayan yapılar içerisinde bireye ve topluma sağlıklı yaşam bilgisi, isteği kazandırarak davranışlara yansımasını sağlamak ve sağlıklı, kişisel, sosyal ve çevresel ortamlar oluşturmaktır (Sorgutan,1993 aktaran Bayın ve Akbulut, 2012:61)

Sağlık sisteminde önemli bir rol oynayan kurumlar olarak hastaneler, sosyal, ekonomik ve çevresel konuları sağlık bakımı ve sağlığın teşviki ile bütünleştirilerek daha fazla kar elde edebilirler (Tenas, Coenders ve Serrat, 2019: 2) Fakat hastanelerde sosyal sorumluluk faaliyetlerini harekete geçirmek zor olabilmektedir. Bunun nedeni bazı paydaşların çıkarlarının sağlık sisteminin ana amaçlarına aykırı olabilmesidir. Bu durum sağlık kurumlarının yönetiminde birtakım sıkıntılara sebep olsa da genellikle hastaneler yönetim kararlarında sosyal sorumluluk anlayışın belirli girişimlerle içselleştirmekte ve uygulamaktadır (Yeşiltaş ve Erdem, 2017:117). Sosyal Sorumluluk anlayışını bir hastanenin strateji ile bütünleştirmek, o hastanenin faaliyet gösterdiği rekabet ortamının, hastane amaçlarıyla ve özellikle de kuruluşun ve paydaşlarının güçlü yönlerinin iyi anlaşılmasını gerektirir. Bundan dolayı, sosyal sorumluluk faaliyetleri bir hastanenin stratejik planlama ve izleme süreciyle sıkı bir şekilde bağlantılı olmalıdır (Takahashi, Ellen ve Brown, 2013: 178).

Hastaneler sorumlu kuruluşlar olarak, sosyal sorumluluk faaliyetlerinin ekonomik, sosyal ve çevresel boyutlarını göz önünde bulundurmalıdırlar. Sosyal sorumluluk araçlarını finansal olmayan göstergeler olarak tanımlamak mümkündür ve hastanelerde finansal olmayan bilgilerin, finansal göstergeler üzerindeki olumlu ekonomik etkisini analiz eden çalışmalar, sosyal sorumluluğun önemli derecede katma değer sağladığını göstermiştir (Tenas, Coenders ve Serrat, 2019: 2). Sosyal sorumluluk kavramı bir kuruluşun yalnızca finansal ve yasal görevlerini yerine getirmesi değil, aynı zamanda sosyal faydaya etkin bir şekilde katkıda bulunması gerektiği anlamına gelir. Kamu yararı için etik davranışa örnek olarak birçok eğitim hastanesinin hayvan refahı için faaliyetler geliştirmiş olması ve hatta bu sorunlarla ilgilenmek için özel etik komiteler oluşturmuş olması gösterilebilir (Brandão, Rego, Duarte ve Nunes, 2013: 394). Sağlıkta kurumsal sosyal sorumluluk anlayışı kapsamında kaliteli sağlık hizmeti sunumu ve yararlı işler ortaya çıkarmak etik bir zorunluluktur 
(Yeşiltaş ve Erdem, 2017:117).

Sağlık kurumlarının kaliteli hizmet, ileri teknoloji ve dengeli fiyatları hedeflemenin yanı sıra, kullanıcıların, profesyonellerin ve toplumun saygısını kazanmaları gerekir. Hastane sektöründe sosyal ve çevresel etki, malzeme ve enerji tüketimi açısından büyük önem taşımaktadır. Bu nedenle, hastane kurumları sosyal, ekonomik ve çevresel yönleri sağlık hizmetleri ve tanıtımına entegre etmelidir (Tenas, Coenders ve Serrat, 2019: 2). Ayrıca tıpkı sosyal yaşamın diğer yönleri gibi, sağlık hizmetlerinin sunumu da evrensel etik ilkelere uygun olarak, insana ve onun temel haklarına saygı gösterilerek yürütülmesi gerekmektedir (Brandão, Rego, Duarte ve Nunes, 2013: 391). Sağlık için sosyal sorumlulukla ilgili biyoetik ve sağlık politikasındaki tartı̧maların çoğu, toplumun sağlık hizmetlerine erişim sağlama yükümlülüğüne odaklanmıştır. Sağlık hizmetlerine erişimin sağlanması önemli bir sosyal sorumluluk olsa da, toplumlar sağlığı sanitasyon, kirlilik kontrolü, gıda ve ilaç güvenliği, sağlık eğitimi, hastalık gözetimi, şehir planlaması ve iş sağllı̆ gibi birçok başka yolla da geliştirebilir. Çevre ve halk sağlığı ve sağlık araştırmaları gibi sağlık hizmetlerine erişim dışında sağlı̆̆ın teşviki stratejilerine daha fazla dikkat edilmelidir (Resnik,2007: 444). Örneğin topluma ölümcül bir hastalığın teşhis ve tedavi süreciyle ilgili gelişmeler hakkında bilgi sunmak, çeşitli hastalıklarda erken teşhis ve tedavinin önemi konusunda farkındalık yaratmak, anne sütünün bebekler için çok önemli olduğunun açıklanması gibi bilimsel bilgilerin aktarılması; insanların sigara, alkol gibi kötü ve zararlı alışkanlıklardan uzaklaştırıp iyiye yönlendirilmesi; sağlıklı kilo verme konusunda bilgilerin sunulması, düzenli diş fırçalamak gibi sağlıklı davranışlara teşvik edilmesi vb faaliyetlere ek olarak aile planlaması ve aşı kampanyası şeklindeki faaliyetler de sosyal sorumluluk kapsamındaki faaliyetler içerisindedir (Bayın ve Akbulut, 2012:58). İskandinavya'da sağlık hizmeti sunan Aleris, Batı Afrika'da Ebolo virüsüyle mücadele çabalarına destek vermiş ve ayrıca 60 ülkede faaliyet gösteren gülümseme operasyonu ile, yüz ve ağız ile ilgili cerrahi işlemleri ücret almadan gerçekleştirmiştir. Gine'de sağlık hizmetlerine katkıda bulunmak için hastane ekipman ve sarf malzemelerini temin etmiştir. Bir başka sağlık kurumu olan Amerikan Hastanesi 2011'den sonra hayvan barınaklarına gıda atıkları göndermiş, Romanya'nın Dobruca Bölgesi'nde bulunan muhtaç çocuklara sağlık hizmeti sunmuştur. Ayrıca Türkiye' de de Sağlık Bakanlığı'nın Dumansız Hava Sahası projesi kurumsal sosyal sorumluluk uygulamalarına örnektir (Yeşiltaş ve Erdem, 2017: 118).

Netice itabariyle sağlık kuruluşlarının sosyal sorumluluk kapsamında bu anlamda uyguladığı ve uygulayabileceği eylemlerin başlıkları: Sosyal refah ve dayanışma programlarını desteklemek; Etik standartlara uyan pazarlama stratejileri yürütmek; Canlılar için potansiyel olarak tehlikeli olan toksik, zehirli kalıntılara çözümler sunmak; Hayvan haklarının korunması ile ilgili faaliyetlerde bulunmak; Çevreyi korumak; Karar verme sürecine özel hasta grupları ve Sivil Toplum Kuruluşları (STK'lar) dahil olan politikaların desteklenmesi; Engelliler için yardım hizmetlerinin oluşturulması; Manevi veya dini ihtiyaçları gidermek amacıyla yardım hizmetleri oluşturmak şeklinde sıralanabilir (Brandão, Rego, Duarte ve Nunes, 2013: 394).

\section{$\checkmark$ Sağlık Kurumlarında İletişim Faktörü:}

Kurumsal iletişim; organizasyonun etkileşime girdiği gruplarla ilişkilerine etkin ve verimli bir temel oluşturabilen uyumlu iç ve dış iletişimden ortaya çıkan bir yönetim aracıdır. Bu araç, kurumlarca kasıtlı olarak gönderilen görsel ve sözlü mesajlar içermektedir (Tuna, Tuna 2007 aktaran Emül ve Naldöken, 2019: 363). Kurumsal iletişim, kurum ile ilgili faaliyetlerde birim, çalışan ve şirketin çevresi arasındaki mesaj trafiğidir. Kısaca kurum hakkındaki bilgileri kurum ortamıla paylaşma sürecidir(Tutar ve Yılmaz 2013 aktaran Aras, 2019: 45). İletişim çerçevesinde, alıcı ve verici arasındaki mesajı anlamak ve alıcı tarafından anlamlı işareti çözmek için, bu işaretin anlamını bilmek, diğer bir deyişle kültürel kodlarla eşleşmesini anlamak zorunludur. En anlaşlır şekilde iletişim, herhangi bir bilgiyi bir mesaj şeklinde gönderme ve alıcının onu yorumlama aşamasıdır. Kurumsal iletişim ile ilgili olarak, bu süreç kurum ve hedef topluluk arasında gerçekleşir (Aras, 2019: 45). Bazen kurum ve müşteri arasındaki hoş bir olay, kurumsal imajı iletişim kanalları aracılığıyla çok olumlu yönde etkiler ve bazen küçük bir hata, yıllar süren çalışma sonucunda ulaşılan olumlu imajı çok düşük düzeylere indirebilir. Bundan dolayı kurumların, müşteriler ve basın ile iletişimlerini yüksek seviyede tutmaları önemlidir (Kanoğlu, 2016:22).

Bir kurum pozitif ve etkili bir imaj oluşturması amacıyla iletişim yöntem ve tekniklerini kullanarak etkileşime girdiği hedef gruplarla iyi ilişkiler içinde olması gerekmektedir. Kurumsal imajı etkileyen faktörler arasında ayrıca sponsorluk faaliyetleri, reklam, halkla ilişkiler gibi iletişim faktörleri yer almaktadır (Semerci,2016: 26). 
Kurumların kültürü, pazarlama faaliyetlerine ve satışlarına fayda sağlayabilmektedir. Bu durum şirket çalışanları dışındaki paydaşları bilgilendirmek, ortaklarla bağları güçlendirmek ve müşteriler dışındaki kişilerle bağlar kurmak açısından çok önemlidir. Bu şekilde satış, pazarlama ve reklamlar fayda sağlar ve finansal gelişime yardımcı olur. Kurumsal iletişim, kurumsal imaj kavramına fayda sağlayan en önemli unsurlardan biridir (Erkan,2014: 49).

Sağlık alanında faaliyette bulunan kurumlar açısından bakıldığında da hedef kitleye ulaşmanın ve onlar üzerinde arzulanan farklılı̆̆ yaratmanın diğer kurumlara göre daha önemli olduğu ve olumlu imaj yaratma sürecinde planlanan iletişim faaliyetlerinin etkisinin daha fazla olduğu görülmektedir. Sağlık sektörü aşırı uzmanlaşma, fonksiyonel bağımlılık, hasta memnuniyeti vb. birtakım özgün özelliklere sahiptir (Somunoğlu, Erdoğan ve Özer, 2013: 7). Bu özelliklere rağmen son zamanlarda sağlık sektöründe bazı değişiklikler görülmektedir. Sağlığın öznesi artık hekimler ya da diğer sağlıkçılardan, toplum ve bireylere doğru, insanların davranışlarına doğru kaymaktadır. Sağlıkla ilgili tercihlerin bireysel yapılması, hatta sağlık politikalarında dahi toplumun daha fazla kontrolde olmasından dolayı artık sağlık profesyonellerinin insanlar ve toplum ile iletişiminde farklılaşmalar doğurmuştur (Erbaydar, 2003: 47). Bu doğrultuda sağlık sektöründe ticarileşmenin artışı ile birlikte oluşan şartların iletişim sürecine etkisi sayesinde sağlık hizmetlerinde halkla ilişkiler, pazarlama ve reklam kampanyaları odak noktası haline gelmiş ve bu faaliyetlerde gözlenen artış, müşteriler ile interaktif iletişimin, ihtiyaç ve taleplere cevap vermenin ve bilgi arama davranışı sonucunda yeni iletişim teknolojilerinin önemini artırmıştır. Bundan dolayı kurumlar arasında referans kaynakları içerisinde ön plana çıkma yarışının başlaması mümkündür (Turancı ve Bulut, 2016:42).

Sağlık iletişiminin amacı; evrensel sağlık vizyonu oluşturmak, kapsamlı bir şekilde toplumun katılımını kapsayan hedefler zincirinin ortaya konulmasını sağlayarak bilgiye erişimin tüm taraflarca etkin yönetimini gerçekleştirmektir. Bu amaçlar için sağlık iletişimi bireysel, kurumsal ve toplumsal çıkarları dengelemelidir (Başol, 2018: 6). Sağlık sektöründe hem sağlık mesleği mensuplarının hem de hastaların beklentilerini öğrenmek için çalışanlar ve hastalar arasında iki yönlü bir iletişim kurmak gerekir. Hedef kitlenin değerlerine dikkat etme, sağlık hizmetleri konusunda farkındalık yaratma, sağlıklı bir yaşam tarzını teşvik etme ve toplumda davranış değişikliği yaratma sürecinde etkili bir iletişim kurmak önemlidir ve bu gelişmeler uzun vadede olumlu kurumsal imaj oluşumuna katkı sağlayacaktır (Somunoğlu, Erdoğan ve Özer, 2013: 7-8).

Kurumsal iletişimin amac1; hedef kitlelerde güvenilir ve istenen bir kurumsal imaj oluşturmaktır. Medya, internet ve kurumlarla ilgili çeşitli organlarındaki haberler ve yayınlar kurumsal imajı olumlu ya da olumsuz yönde etkilemektedir. Günümüzde sosyal medyanın (facebook, twitter, vb.) artan kullanımı, kurumsal imaj oluşturmada ve oluşturulan kurumsal imajı hedefe ulaştırmada oldukça önemlidir (Kanoğlu, 2016: 22). Sağlık kurumlarında yararlanılan medya araçlarının çeşitlenmesi, iletişim stratejilerindeki farklılaşmalardan dolayıdır. Özellikle günümüzde dijital medyanın önemli olması sağlık kurumlarının ve bireylerin bu kanallara yönelmesine sebep olmuştur. Bilgiye ulaşım sürecinde sağladıkları kolaylık nedeniyle kişilerin internette sıklıkla bilgi aradıklarını söyleyebiliriz (Turancı ve Bulut, 2016: 48).

Sağlık kurumlarında iletişimin başarısı insanların ihtiyaçlarına, dil ve kültürel yapılarına en uygun içerik ve yöntemlerle sağlık mesajlarının en kolay algılanan ve anlaşılır şekilde verilmesine bağlıdır. Bu, toplumla iyi bir iletişime bağlıdır. Hangi yollarla topluma hangi mesajlar verilecek? Hangi gruplar önemlidir ve bu gruplardan hangileriyle hangi programlar hangi araçlarla yürütülecektir? Kişiler için hangi hizmetler ihtiyaçtır? Ulusal, bölgesel veya kurumsal ölçekte politikalar var mı ve bu konuda yapılması gerekenler nelerdir? Bu tarz soruları cevaplamak, bir sağlık iletişimi programının sistematize edilmesinde yardımcı olacaktır (Erbaydar, 2003:49). Sonuçta sağlık kurumlarındaki topluma görünür olma arzusu, farkındalıklarını artırma çabaları ve rekabet şartlarında varlıklarını sürdürme amaçları gibi sebepler; engeller ve yaptırımlar olsa da birçok medya aracını reklam, tanıtım ve pazarlama amaçlı olarak etkin bir şekilde kullanmalarına sebep olmaktadır (Turanc1 ve Bulut, 2016: 59).

\section{$\checkmark$ Sağlık Kurumlarında Kalite Faktörü:}

Kalite kavramı ilk olarak sanayi devriminin ardından ortaya çıkmıştır. Hizmet kalitesi ise 1980'li yıllardan sonra hizmet sektörünün hızlı gelişimi ile beraber üzerinde çalışmalar yapılan bir kavram olmuştur (Koç, 2017: 229). Hizmetin kaliteli sunumu günümüz rekabet koşullarında başarı ve yaşamını devam ettirebilmek amacıyla öncelikli bir strateji olarak kabul edilir. 1980'lerde, hem akademik hem de yönetsel çabaların birincil vurgusu, müşteriler için hizmet kalitesinin anlamını ortaya koymaya ve müşteri beklentilerini karşılayacak 


\section{K. G. Yilmaz - E. Saygin - M. Tolon 13/3 (2021) 2780-2799}

stratejiler geliştirmeye odaklanmıştır (Zeithaml, Berry ve Parasuraman, 1996: 31).

Kalite geçmişten günümüze kadar pek çok kez farklı şekillerde tanımlanmıştır. Bu tanımlardan bazıları: Kalite; ürünün değeridir, geçmişte belirlenen niteliklere uygunluktur, ihtiyaca uygunluktur, "kullanıma uygunluktur" ( Juran), "şartlara uygunluktur" (Crosby), ürünün saptanan ya da ortaya çıkabilecek ihtiyaçları karşılama yeteneği ile ilgili özelliklerin toplamıdır (ISO 9905) şeklindedir (Tengilimoğlu, 2016: 316).

Literatürde kalitenin kavramsal olarak evrensel bir tanımının olmaması ile birlikte yapılan birçok tanımın ortak unsurları bulunmaktadır. Bunlar: "Kalite, müşteri beklentilerini karşılamayı ve aşmayı içerir. Kalite dinamiktir (yani bugün kalliteli olarak görülen şey, yarm kaliteli bulunmayabilir). Kalite iyileştirilebilir" şeklindedir (Kaya S, Tengilimoğlu D, Işık O, Akbolat M ve Yılmaz A, 2014: 3). Sonuç olarak kalitenin sürekli gelişime öncülük eden içerisinde yönetsel ve istatiksel metotdolojileri barındırmasının yanı sıra yöneticileri, çalışanları, müşterileri, tedarikçileri ve toplumu kapsayan bir felsefe olduğunu söylemek mümkündür.

Kalite kavramı günümüz iş dünyasında stratejik bir unsur olarak ele alınırken, müşteriler tarafından bakıldığında onların seçimlerini etkileyen temel faktörlerden birisi olmaktadır ( Kayral, 2015:29). Diğer yandan algılanan kalite müşteriler nezdinde marka ve unsurlarının nasıl yorumlandığı ile de ilgilidir (Aktepe ve Baş, 2008, 84). Nitekim Juran'ın ortaya koyduğu tasarım ve uygunluk kalitesinin literatüre kazandırılmasında da bu bakış açılarının temel alındığı düşünülebilir. Bu ikisine ek olarak performans kalitesi de temel kalite bileşenleri arasındadır. Tasarım kalitesi müşterilerin istek ve ihtiyaçların uygun karşılanmasını; karşılandığı sürecin beklentilere uygunluğu ve ödenilen bedel karşısında tatmin olma düzeyini ifade ederken (Taşçı, 2013: 29), Uygunluk kalitesi önceden belirlenmiş spesifikasyonlara ve standartlara uygunluğu ifade eder, yani üründen beklenen niteliklerin istatistiksel kalite kontrol denetiminin belirlediği sınırlar içerisinde normal değerlerden sapma düzeyidir (Karakaya, Kılıç ve Uçar, 2016: 43). Performans kalitesi ise kurumun gereklilik ve hedeflerini en iyi etkin etkili ve verimli şekilde sonuçlandırmak için kaynaklar ile çıktının uyumlu bir şekilde planlandığı gibi olması bakımından gerçekleştirilen değerlendirme sürecidir. Performans kalitesinin arzu edilen düzeyde olabilmesi için hedeflerin ölçülebilir olmasının yanı sıra çıktılarının da devamlı olarak ölçülmesi gerekmektedir (Tunçel, Doğan ve Çobaner, 2012: 104).

Netice itibariyle kalite; ürünün, müşterilerin talep ve ihtiyaçlarını karşılama çabasında maddi ve manevi doygunluğa ulaşma gücüyle ortaya çıkan yetenek ve performans ölçüsüdür. Planlı işlevselliklere uygun olarak hatasız performans gösterme yeteneği ve iş başarma gücüdür. Müşteri tarafından ödenen fiyattan memnuniyet düzeyidir.

Kalite yönetimi: yüksek rekabet gücü, müşteri memnuniyeti, hataların engellenmesi, israfın ortadan kaldırılması ve maliyetlerin düşürülmesini sağlayarak pazar payının ve kârlılığın artırılmasında önemli bir faktördür( Kayral, 2015: 30-32). Üretim aşamasında yaşanacak kaynak israfı ve hata, verimliliğin düşüşü ile birlikte ek olarak maliyet artışına neden olur. Ayrıca hatalar ve müşteri açısından değer yaratmayan israflar sonucunda müşteri ödediği fiyattan memnun kalmadığını algılarsa, bunun sonucu olarak, müşteri memnuniyetsizliği ile beraber pazar payında azalmaya yol açar. Bu durumda olumlu bir imaj sahibi olmak mümkün hale gelmez .

Müşteriler kaybedildiğinde, onların yerine yenilerinin çekilmesi gerekir ve değişimin maliyeti yüksek olur. Çünkü yeni müşteriler kazanmak pahalıdır reklam, promosyon ve satış maliyetlerinin yanı sıra başlangıçtaki işletme giderlerini de içerir. Yeni müşteriler genellikle edinimden sonra bir süre için kârsızdır: Örneğin sigorta endüstrisinde, sigortacı tipik olarak ilişkinin üçüncü veya dördüncü yılına kadar satış maliyetlerini karşılayamaz (Zeithaml, Berry ve Parasuraman, 1996: 33).

Ek olarak kalite faktörü ele alınırken; hizmet ve mamul mallar arasında büyük farklılıkların olduğu göz önünde bulundurulmalıdır. Hizmet pazarlamacıları kaliteyi anlamak ve kontrol etmekte zorluk yaşarlar. Hizmetlerin üretim ve tüketimin ayrılmazlığı, hizmetin soyutluğu, hizmetlerin stoklanamaması, hizmetlerin heterojenliği (standardizasyonunun zor olması), sahipliğinin olmaması gibi farklılıkları kalite yönetimi yaklaşımı ve özü üzerinde etkisi vardır (Ghobadian, Speller ve Jones, 1994: 47-48). Hizmetler nesnelerden çok performans oldukları için, tek tip kalite için kesin üretim spesifikasyonları nadiren firma tarafından oluşturulabilir ve yürürlüğe konabilir. Hizmetlerde kalite, üretim tesisinde tasarlanıp tüketiciye bozulmadan teslim edilmez. Kaliteli teslimatı sağlamak için çoğu hizmet satıştan önce sayılamaz, ölçülemez, envantere kaydedilemez, test edilemez ve doğrulanamaz. Ayrıca, hizmetlerin performansı özellikle yüksek iş gücü 
içeriğine sahip olanlar çalışanlar arasında, müşteriler arasında ve günden güne farklılık göstermektedir. Çoğu hizmette kalite, hizmet sunumu sırasında, genellikle müşteri ile hizmet firmasının iletişim personeli arasındaki etkileşimde ortaya çıkar. Bu nedenle, hizmet kalitesi büyük ölçüde çalışanların performansına bağlıdır ve somut malların bileşenlerinin tasarlanabildiği ölçüde kontrol edilemeyen örgütsel bir kaynaktır Ayrıca müşterilerin hizmet kalitesi algıları ve kurumu tavsiye etme istekleri arasında olumlu bir ilişki vardır (Zeithaml, Berry ve Parasuraman, 1988: 35). Örneğin Sağllk turizminin Türkiye'de gelişim süreci incelendiğinde, özellikle müşterilerin hizmet kalitesi unsurları içinde bir hizmet unsuru olan fiziksel özellikleri öne çıkardığı görülebilmektedir (Aktepe 2013, 177).

Hizmet kalitesi müşterilerin beklentilerini karşılamak amacıyla en iyi hizmetin verilmesidir. Hizmet kalitesi kurumun müşteri beklentilerini karşılayabilme ve hatta günümüzde beklentilerin de üzerine çıkabilme becerisidir (Göker ve Gümüş, 2012: 28).

1988'de Parasuraman, Zeithaml ve Berry hizmet kalitesini ölçmek için SERVQUAL yaklaşımını geliştirmiş hizmet kalitesinin "beklenti / performans" kavramsallaştırmasını ortaya koymuşlardır ve literatürdeki en genel kabul görülen tanımın ( Hizmet kalitesi: müşterilerin bir kurumdan bekledikleri ya da almayı ön gördükleri hizmet ile hizmetin tüketimi sonrasındaki algılama düzeylerinin arasındaki farktır) ortaya çıkışını sağlamışlardır (McAlexander, Kaldenberg ve Koenig, 1994: 35). Zeithaml, Berry ve Parasuraman (1988) ortaya koymuş oldukları model ile oluşturdukları; literatürde sağlık sektörü de dahil bir çok hizmet sektörü ile ilgili kalite ölçüm araştırmalarında kullanılan servqual ölçeğinde hizmet kalitesinin 5 boyutunu belirlemişlerdir. Bunlar, fiziksel özellikler, güvenirlilik, güven, empati ve heveslilik boyutlarıdır. O halde hizmet kalitesinin bu beş faktörün dikkate alınarak yükseltilmesi gerektiğini söyleyebiliriz.

Çok sayıda araştırmacı, hizmet kalitesinin müşteri sadakati yaratmadaki etkisini araştırmıştır. Hizmet kalitesi, müşteri memnuniyeti, kurumsal imaj, ağızdan ağza iletişim algılanan değer sadakatin öncülleri olarak önerilmiş ve bu değişkenler aynı zamanda rekabet avantajı ve kurumsal başarının itici gücü olarak saptanmıştır. Kurumsal imajın en önemli nedeni, değeri artıran ve hafızada daha erişilebilir hale gelen hizmetlerin değerlendirilmesidir (Ishaq, 2012: 26). Özellikle sağlık hizmetleri gibi emek yoğun hizmetlerde hizmetlerin performansı hizmeti alan müşteriler ile sunan kurumun personeli arasındaki uyumlu etkileşim ile yakından ilgilidir. Bu etkileşimler hizmeti satın almamış potansiyel müşterileri ve beklentilerini etkileyecektir. Çünkü beklentiler, mal veya hizmetin genel performansı ile ilgili olarak, önceki tecrübeler, sağllk hizmeti tüketicilerinin reklam ve satışlar yoluyla etrafından edindiği bilgiler, kurumun imajı, müşterilerin ihtiyaçları ve ağızdan ağıza iletişimler ile hizmet satın alınmadan önce oluşturulur (Altunışık, 2015: 61-62). Sağlikta kalite, teknik ve fonksiyonel olmak üzere iki boyutu kapsamaktadır. Teknik boyut hemşire ve doktor hizmetini içerirken, fonksiyonel boyut yemek servisi, gürültü, oda sıcaklığı ve konforu, temizlik, hastanenin park alanı gibi fiziksel özellikleri içermektedir. Çalışmalar, fonksiyonel kalitenin hastaların kalite algısını etkileyen ana unsur olduğunu göstermiştir (Taşdemir, Oğuzöncül ve Durmuş, 2015:6). Hastaneler hizmet kalitesinin belirleyicisi olan bu bileşenleri ve hizmet kalitesinin boyutlarını dikkate alarak ve oralarda iyileştirmeler sağlayarak hastalara üstün kalitede hizmet sunumu gerçekleştirebilirler. Woodside. Frey ve Daly (1989) araştırmalarında genel hasta memnuniyeti ile hastaneyi tekrar seçme niyeti arasında önemli bir ilişki olduğunu ortaya çıkarmıştır. Sonuç olarak günümüz rekabet şartlarında iyi bir kurumsal imaj sağlayarak müşteri sadakatini sağlamak kurumların sürdürülebilirlilikleri açısından bir zorunluluktur. Bu durum da müşteri memnuniyetini sağlamayı gerektirir. Hizmet sağlayıcılar sunumuna sürekli ve dinamik olarak değer katmalı ve bu sayede olumlu imaj ortaya çıkararak müşteri sadakati yaratabilmelidir. Müşteri memnuniyetini artırarak ve üstün kalitede hizmet sunarak diğer sektörlerde olduğu gibi sağlık kurumlarıda da rakiplerinden farklılaşarak olumlu imaj oluşturabilir, satış ve karını artırabilir (Çatı ve Baydaş, 2008:248-250-251).

\section{YÖNTEM}

\subsection{Araştırmanın Amacı ve Hipotezi}

Araştırmanın amacı kurumsal imaj algı düzeyi ile kurumsal imaj faktörleri arasındaki ilişkiyi ve etkiyi ortaya koymaktır.

Bu doğrultuda aşağıdaki hipotezler geliştirilmiştir.

H1: Kurumsal imaj algı düzeyi ile kurumsal imaj faktörleri arasında ilişki vardır. 
K. G. Y1lmaz - E. Saygin - M. Tolon 13/3 (2021) 2780-2799

H2: Kurumsal imaj faktörlerinin kurumsal imaj algı düzeyi üzerinde etkisi vardır.

H3: Kurumsal imajı oluşturan faktörlerden (a)fiziksel ortam faktörünün, (b)iletişim faktörünün, (c)kalite faktörünün, (d) sosyal sorumluluk faktörünün kurumsal imaj algı düzeyi üzerinde etkisi vardır.

\subsection{Araştırmanın Kapsamı Evreni ve Örneklemi}

Çalışmanın verileri yüz yüze anket yöntemi ile Ankara'da bir özel hastanenin 18 yaşını doldurmuş müşterilerinden toplandı. Çalışmanın evreni, bu özel bir hastanede, yataklı tedavi biriminden 03.05.2021 ile 04.06.2021 tarihleri arasında hizmet alan 18 yaş üstü hasta sayısı olan 423 bireydir.

Araştırmada evrenin tamamına ulaşılamayacağı için örneklemeye gidilmiştir. Evrenin 423 kişiden oluştuğu bu araştırmada, evreni temsil edebilecek örneklem sayısı \% 95 güven ve \% 5 duyarlılık düzeyinde 202 kişi olacak şekilde saptanmış ve 213 örneklem sayısı ile çalışma yapılmıştır. Araştırmamızda örneklem sayısının nasıl belirlendiği aşağıda ifade edilmiştir.

Sayısı belirli olan bir evrende çalı̧̧ma yapılıyorsa örneklem sayısını hesaplamak amacıyla aşağıda yer alan formül kullanılmaktadır (Sümbüloğlu ve Sümbüloğlu, 1998:264- 265):

$$
\mathbf{n}=\frac{N \cdot t^{2} \cdot p \cdot q}{d^{2} \cdot(N-1)+t^{2} \cdot p \cdot q}
$$

n: Örneklem sayısı

$\mathrm{N}$ : Evrenin sayisı

p: İncelenen olayın görülüşs sıklığı/olasılı̆̆g $(0,5)$

q: İncelenen olayın görülmeyiş sıklı̆̆1/olasılığı $(0,5)$

t: Belirli serbestlik derecesinde ve saptanan hata düzeyinde $t$ tablosundan bulunan teorik değer $(1,96)$

$\mathrm{d}$ : Olayın görülüş sıklığına göre yapılmak istenen \pm sapma $(0,1)$

Araştırmada yatan hasta biriminde hizmet alan (18 yaşından büyük) kişi sayısı 423 kişi olup, 240 anket toplanmıştır. Çalışmaya geçerli olan 213 anket formu dahil edilerek veriler analiz edilmiştir. Basit tesadüfi örnekleme yöntemi kullanılmıştır.

\subsection{Veri Toplama Araçları}

Araştırmada anket yöntemi ile veri toplanmıştır. Ankette üç bölüm yer almaktadır. Birinci bölümde, örneklemin demografik özelliklerinin anlaşılmasına yönelik ifadeler bulunmaktadır. İkinci bölümünde, kurumsal imaj algı düzeyinin saptanmasına ilişkin maddeler bulunmaktadır. İkinci bölümde yer alan maddeler Derin ve Demirel (2010: 177) tarafından geliştirilen ve 7 maddelik Kurum İmajı Ölçeğinden uyarlanmıştır. Üçüncü bölümde ise, kurumsal imajı faktörleri (fiziksel, iletişim, kalite, sosyal sorumluluk faktörleri) ile ilgili 26 önerme bulunmaktadır. Anket Karaosmanoğlu (2006) tarafından geliştirilmiş ve Bayın (2013) tarafından sağlık sektörüne uyarlaması, geçerlilik ve güvenirliliği yapılmıştır. Ölçeklerde bulunan ifadeler, 5'li Likert tipinde "1=kesinlikle katılmiyorum", "2=katılmiyorum", "3=kısmen katılıyorum", "4=katılıyorum" ve "5=kesinlikle katılıyorum" şeklinde değerlendirilmiştir.

\subsection{Veri Analizi}

Verilerin analiz edilmesi için SPSS 22.0 istatistik paket programından yararlanılmıştır. Yapılan veri analizlerinde tanımlayıcı istatistikler hesaplanmıştır. Kurumsal imaj algısı ile Kurumsal imaj faktörleri arasındaki ilişkiyi ortaya koymak amacıyla korelasyon ve doğrusal regresyon analizleri yapılmıştır. Ortaya çıkan bulgular \% 95 güven aralığında ve \% 5 anlamlılık düzeyinde incelenmiştir. 
K. G. Yilmaz - E. Saygin - M. Tolon 13/3 (2021) 2780-2799

\section{BULGULAR}

Tablo 1. : Demografik Özellikler

\begin{tabular}{|l|l|c|c|}
\hline Değişkenler & Frekans & \% \\
\hline \multirow{3}{*}{ Cinsiyet } & Kadın & 105 & 33,3 \\
\cline { 2 - 4 } & Erkek & 108 & 50,7 \\
\hline \multirow{5}{*}{ Yaş } & $18-25$ & 12 & 5,6 \\
\cline { 2 - 4 } & $26-35$ & 28 & 13,1 \\
\cline { 2 - 4 } & $36-45$ & 73 & 34,3 \\
\cline { 2 - 4 } & 46 ve üzeri & 100 & 46,9 \\
\hline \multirow{5}{*}{ Eğitim Durumu } & Lise veya Alt1 & 46 & 21,6 \\
\cline { 2 - 4 } & Önlisans & 29 & 13,6 \\
\cline { 2 - 4 } & Lisans & 86 & 40,4 \\
\cline { 2 - 4 } & Lisansüstü & 52 & 24,4 \\
\hline \multirow{5}{*}{ Medeni Durum } & Bekar & 61 & 28,6 \\
\cline { 2 - 4 } & Evli & 152 & 71,4 \\
\hline & Toplam & 213 & 100 \\
\cline { 2 - 4 } & & &
\end{tabular}

Tablo 2: Özel Hastaneden Hizmet Almayı Tercih Etme Durumu

\begin{tabular}{|c|c|c|}
\hline Özel Hastaneden Hizmet Alma & Sayı & Yüzde \\
\hline Evet & 190 & 89,2 \\
\hline Hayır & 23 & 10,8 \\
\hline Toplam & 213 & 100 \\
\hline
\end{tabular}

Çalışmaya dahil olan 213 müşterinin 105'i (\% 49,3) kadın, 108'1 ise (\% 50,7) erkektir. müşterilerin yaş aralıklarının dağılımı incelendiğinde, 12 bireyin (\% 5,6) 25 veya altı yaş aralığında, 28 bireyin (\% 13,1) 26-35 yaş arasında, 73 bireyin (\% 34,3) 36-45 yaş aralığında, 100 bireyin ise $(\%$ 46,9) 46 veya üzeri yaş aralığında olduğu görülmüştür.

Bireylerin eğitim seviyesine bakıldığında, 46 bireyin (\% 21,6) lise veya altı, 29 bireyin (\% 13,6) ön lisans, 86 bireyin (\% 40,4) lisans, 52 bireyinde de (\% 24,4) lisansüstü eğitim düzeyinde olduğu görülmüştür. Müşterilerin 61 'i $(\%$ 28,6) bekar, 152'si de (\% 71,4) evlidir.

Bireylere öncelikli olarak özel hastaneden hizmet almayı tercih edip etmeyecekleri sorulduğunda 190 birey $(\% 89,2)$ evet, 23 birey (\% 10,8) hayır cevabını vermiştir.

Tablo 3 : Araştırmaya Katılan Örneklem Grubunun İmaj Faktörleri ile İmaj Algısı Arasındaki İlişki

\begin{tabular}{|c|c|c|c|c|c|c|}
\hline & & 1 & 2 & 3 & 4 & 5 \\
\hline \multirow[t]{3}{*}{1 Fiziksel ORT } & Pearson Korelasyonu & 1 & $814^{* *}$ & $782^{* *}$ &, $762^{* *}$ &, $635^{* *}$ \\
\hline & Sig. (2-tailed) & &, 000 &, 000 &, 000 &, 000 \\
\hline & $\mathrm{N}$ & 213 & 213 & 212 & 212 & 213 \\
\hline \multirow[t]{3}{*}{2 İletişim Faktörü } & Pearson Korelasyonu & $814^{* *}$ & 1 & $874^{* *}$ & $858^{* *}$ & $681^{* *}$ \\
\hline & Sig. (2-tailed) & ,000 & & , 000 & 000 & ,000 \\
\hline & $\mathrm{N}$ & 213 & 213 & 212 & 212 & 213 \\
\hline \multirow[t]{3}{*}{3 Kalite Faktörü } & Pearson Korelasyonu &, $782^{* *}$ & $874^{* *}$ & 1 & $888^{* *}$ & $662^{* *}$ \\
\hline & Sig. (2-tailed) & ,000 &, 000 & &, 000 & ,000 \\
\hline & $\mathrm{N}$ & 212 & 212 & 212 & 212 & 212 \\
\hline \multirow{3}{*}{$\begin{array}{l}4 \text { Sosyal Sorumluluk } \\
\text { Faktörü }\end{array}$} & Pearson Korelasyonu &, $762^{* *}$ & $858^{* *}$ & $888^{* *}$ & 1 &, $575^{* *}$ \\
\hline & Sig. (2-tailed) & ,000 &, 000 & ,000 & & ,000 \\
\hline & $\mathrm{N}$ & 212 & 212 & 212 & 212 & 212 \\
\hline \multirow[t]{3}{*}{5 Kurumsal İmaj Alg1 } & Pearson Korelasyonu & $635^{* *}$ & $681^{* *}$ & $662^{* *}$ &, $575^{* *}$ & 1 \\
\hline & Sig. (2-tailed) & ,000 & ,000 & ,000 & ,000 & \\
\hline & $\mathrm{N}$ & 213 & 213 & 212 & 212 & 213 \\
\hline
\end{tabular}


K. G. Yilmaz - E. Saygın - M. Tolon 13/3 (2021) 2780-2799

Kurumsal imajı oluşturan faktörler ile algılanan imaj arasında ilişki olup olmadığı tablo 3 te gösterilmiş olup her bir boyut ile algılanan imaj arasında 0,05 önem düzeyinde anlamlı ilişki tespit edilmiştir. $\mathrm{H}_{1}$ hipotezi yeterli kanitla desteklenmiştir.

Tablo 3'den de anlaşılacağı üzere imaj faktörleri ile imaj algısı arasındaki ilişki analiz edilmiştir. Buna göre Fiziksel Ortam ortalaması boyutu ile imaj algısı arasındaki ilişki r:,635 olarak tespit edilmiştir. Diğer yandan iletişim boyutu ile imaj algısı arasındaki ilişki r:0,681 olarak tespit edilmiştir. Kalite boyutu ile algılanan imaj arasındaki ilişki r:0,662 olarak tespit edilmiştir. Sosyal faktörler boyutu ile imaj algısı arısındaki ilişki ise, r:0,575 olarak tespit edilmiştir. Diğer bir ifade ile $\mathrm{H}_{1}$ hipotezi ve alt hipotezleri yeterli kanıtla desteklendiği görülmektedir. Dolayısıyla imaj boyutları ile imaj algısı arasında kuvvetli bir ilişkinin bulunduğu söylenebilir.

Tablo-4 İmaj Faktörleri Toplamının Algılanan İmaj Üzerindeki Etkisi

\begin{tabular}{|l|c|c|c|}
\hline Model & R & R Kare & Düzeltilmiş R Kare \\
\hline 1 Fiziksel+Sosyal+İletişim+Kalite &, $712^{\mathrm{a}}$ &, 507 &, 498 \\
\hline
\end{tabular}

Kurumsal imajı oluşturan faktörlerin birleştirilmiş şekli ile algılanan imaj üzerindeki etkisi tablo 4 te gösterilmiştir. Buna göre toplam boyutun algılanan imaj üzerinde etkisi olduğu tespit edilmiştir. H2 hipotezi yeterli kanitla desteklenmiştir. Buna göre r2: 0,507 ile yüksek düzeyde bir açılama değerine sahip olduğu görülmektedir. Dolayısıyla imaj algısının oluşmasında imaj faktörlerinin \% 50'lik bir etkiye sahip olduğu görülmektedir.

Tablo-5 İmaj Faktörlerinin Algılanan İmaj Üzerindeki Etkisi

\begin{tabular}{|l|c|c|c|}
\hline Model & $\mathrm{R}$ & R Kare & Düzeltilmiş R Kare \\
\hline Fiziksel &, $635^{\mathrm{a}}$ &, 404 &, 401 \\
\hline İletişim &, $681^{\mathrm{a}}$ &, 463 &, 461 \\
\hline Kalite &, $662^{\mathrm{a}}$ &, 439 &, 436 \\
\hline Sosyal &, $575^{\mathrm{a}}$ &, 330 &, 327 \\
\hline
\end{tabular}

H3: Kurumsal imajı oluşturan faktörlerden (a)fiziksel ortam faktörünün, (b)iletişim faktörün, (c)kalite faktörünün, (d) sosyal sorumluluk faktörünün kurumsal imaj algı düzeyi üzerinde etkisi vardır.

Kurumsal imajı oluşturan faktörlerin algılanan imaj üzerine etkisi olup olmadığı tablo 3 te gösterilmiş olup her bir boyutun etkisi olduğu görülmüştür. H3 hipotezi yeterli kanıtla desteklenmiştir.

İmajı oluşturan faktörlerin algılanan imaj üzerindeki bireysel etkilerini belirlemeye yönelik yapılan regresyon analizi sonucunda fiziksel boyutun $\% 40$, iletişim boyutunun $\% 46$, kalite boyutunun $\% 43$ ve sosyal boyutun \%33 oranında imajı etkilediği görülmektedir. Diğer yandan tablodan da anlaşılacağı üzere algılanan imaj üzerindeki en önemli faktörün iletişim boyutu olduğu dikkat çekmektedir. Buna karşın etkisi en düşük boyutun ise sosyal faktörler olduğu söylenebilir

Demografik Değişkenlere Göre Farklılaşma Testleri

Tablo-6: Cinsiyet Değişkeni Açısından Algılanan İmaj ve Kurumsal İmaj Orta

\begin{tabular}{|l|l|c|c|c|c|c|}
\hline & Cinsiyet & $\mathrm{N}$ & Anlamlılık & Std. Sapma & $\mathrm{t}$ & $\mathrm{p}$ \\
\hline \multirow{2}{*}{$\begin{array}{l}\text { Algilanan } \\
\text { İmaj }\end{array}$} & Kadın & 105 & 4,0952 &, 72311 & 2,130 & \multirow{2}{*}{, 034} \\
\cline { 2 - 5 } $\begin{array}{l}\text { Kurumsal } \\
\text { İmaj }\end{array}$ & Erkek & 108 & 3,8565 &, 90069 & & \multirow{2}{*}{, 002} \\
\cline { 2 - 5 } & Kadın & 105 & 3,9895 &, 62956 & 3,121 & \\
\hline
\end{tabular}

Hem algılanan imaj hem de kurumsal imaj açısından cinsiyete göre farklılaşma olup olmadığı $t$ testi analizi ile belirlenmiştir. $p$ değerinin 0,05 den küçük olması nedeniyle her iki değişken açısından da farklılık olduğu görülmüştür. Kadınlar, hem algılanan imaj hem de kurumsal imaj açısından erkeklere göre daha yüksek ortalamaya sahiptir. Bununlar birlikte her iki cinsiyet açısından da algılanan imajın ortalama değeri kurumsal imajdan daha yüksektir. Kadınların hastaneye ilişkin olumlu algılarının erkek katılımcılara göre daha yüksek olduğu görülmektedir. 
K. G. Y1lmaz - E. Saygin - M. Tolon 13/3 (2021) 2780-2799

Tablo-7: Yaş Değişkeni Açısından Algılanan İmaj ve Kurumsal İmaj Ortalamalarındaki Farklılaşma

\begin{tabular}{|c|c|c|c|c|c|c|}
\hline \multicolumn{2}{|c|}{ Yaş } & $\mathrm{N}$ & Anlamlılık & Std. Sapma & F & $\mathrm{p}$ \\
\hline \multirow{5}{*}{$\begin{array}{l}\text { Algilanan } \\
\text { İmaj }\end{array}$} & 25 ve altı & 12 & 4,2500 & 65713 & \multirow[t]{5}{*}{3,252} & \multirow[t]{5}{*}{,023 } \\
\hline & 26-35 yaş arası & 28 & 4,2440 & 71360 & & \\
\hline & $36-45$ yaş arası & 73 & 3,7626 & 88537 & & \\
\hline & 46 yaş ve üzeri & 100 & 4,0200 & 79677 & & \\
\hline & Total & 213 & 3,9742 & 82479 & & \\
\hline \multirow{5}{*}{$\begin{array}{l}\text { Kurumsal } \\
\text { İmaj }\end{array}$} & 25 ve altı & 12 & 3,8132 & 1,09294 & \multirow[t]{5}{*}{210} & \multirow[t]{5}{*}{890} \\
\hline & 26-35 yaş arası & 28 & 3,7638 & 85672 & & \\
\hline & $36-45$ yaş arası & 73 & 3,7856 & 81127 & & \\
\hline & 46 yaş ve üzeri & 100 & 3,8668 & 71301 & & \\
\hline & Total & 213 & 3,8224 & ,78628 & & \\
\hline
\end{tabular}

Kurumsal imaj ve algılanan imaj değişkenlerinin katılımcıların yaşlarına göre farklılaşıp farklılaşmadığı Anova testi ile incelenmiştir. Yaş değişkenine göre kurumsal imajda farklılaşma tespit edilememiştir (p:0,890). Algılanan imajda ise farklılık söz konusudur. En yüksek imaj algısı 25 yaş ve altında gerçekleşmiştir. Bu grubun hastaneye ilişkin algıları diğer yaş gruplarına göre daha olumlu olduğu görülmektedir.

Tablo 8: Eğitim Değişkeni Açısından Algılanan İmaj ve Kurumsal İmaj Ortalamalarındaki Farklılaşma

\begin{tabular}{|c|c|c|c|c|c|c|}
\hline \multicolumn{2}{|c|}{ Eğitim } & $\mathrm{N}$ & Anlamlılık & Std. Sapma & $\mathrm{F}$ & $\mathrm{p}$ \\
\hline \multirow[t]{5}{*}{ Algilanan İmaj } & Lise ve altı & 46 & 4,1486 & ,81212 & \multirow{5}{*}{1,325} & \multirow{5}{*}{,267 } \\
\hline & Önlisans & 29 & 3,9943 & ,95793 & & \\
\hline & Lisans & 86 & 3,9690 & 82506 & & \\
\hline & Lisansüstü & 52 & 3,8173 & 74481 & & \\
\hline & Toplam & 213 & 3,9742 & 82479 & & \\
\hline \multirow[t]{5}{*}{ Kurumsal İmaj, } & Lise ve altı & 46 & 4,0415 & 66288 & \multirow{5}{*}{1,556} & \multirow{5}{*}{ 201 } \\
\hline & Önlisans & 29 & 3,7893 & ,88851 & & \\
\hline & Lisans & 86 & 3,7655 & 85955 & & \\
\hline & Lisansüstü & 52 & 3,7411 & 67920 & & \\
\hline & Toplam & 213 & 3,8224 & ,78628 & & \\
\hline
\end{tabular}

Hem algılanan imaj hem de kurumsal imaj açısından eğitime göre farklılaşma olup olmadığı Anova testi analizi ile belirlenmiştir. p değerinin 0,05 den büyük olmasından dolayı her iki değişken açısından da farklılık olmadığı görülmüştür.

\section{TARTIŞMA, SONUÇ VE ÖNERİLER}

$\mathrm{Bu}$ çalışma ile özel hastaneden faydalanan dış müşterilerden veri toplanarak, kurumsal imaj algı düzeyi ile kurumsal imaj faktörleri arasındaki ilişki ve etki ortaya koyulmuştur.

Araştırmada kurumsal imajı oluşturan her bir boyut ile algılanan imaj arasında anlamlı ilişki olduğu tespit edilmiştir. Aynı şekilde alt hipotezlerin de yeterli kanıtla desteklendiği görülmektedir. Bu durum kurumsal imajın boyutları ile imaj algısının arasında güçlü bir bağ olduğunu göstermektedir. Kurumsal imajı oluşturan faktörlerin birleştirilmiş bütünsel formunun algılanan imaj üzerindeki etkisi incelenmiş ve toplam boyutun algılanan imaj üzerinde etkisi olduğu tespit edilmiştir. Ayrıca imaj algısının oluşmasında imaj faktörlerinin \% 50'lik bir etkiye sahip olduğu görülmüştür. Kurumsal imajı oluşturan faktörlerden (a)fiziksel ortam faktörünün, (b)iletişim faktörünün, (c)kalite faktörünün, (d) sosyal sorumluluk faktörünün kurumsal imaj alg1 düzeyi üzerinde etkisi incelendiğinde; her bir boyutun etkisi olduğu görülmüştür. Ancak analiz sonucu incelendiğinde en fazla etki iletişim faktöründe en az etki ise sosyal sorumluluk faktöründedir. Dolayısıyla etki dağılımında homojenite söz konusu değildir. Kendine özgü nitelikleri nedeniyle sağlık hizmeti üreten 
K. G. Yilmaz - E. Saygin - M. Tolon 13/3 (2021) 2780-2799

hastaneler açısından üretilecek stratejilerde bu durum mutlaka göz önünde bulundurulmalıdır. Algılanan imaja yönelik oluşturulacak stratejilerde hedef kitle analizi sonucunda kaynak planlaması etkinliği ve verimliliği maksimize edecek şekilde gerçekleştirilmelidir.

Çalışmanın bulgularına baktığımızda imajı oluşturan faktörlerin algılanan imaj üzerindeki bireysel etkilerinde fiziksel boyutun \% 40, iletişim boyutunun \%46, kalite boyutunun \%43 ve sosyal boyutun \%33 oranında imaj1 etkilediği görülmektedir. Diğer yandan algılanan imaj üzerindeki en önemli faktörün iletişim boyutu olduğu dikkat çekmektedir. Buna karşın etkisi en düşük boyutun ise sosyal faktörler olduğu söylenebilir. Günümüzde insanların dijital platformlara yönelmeleri medyanın internet üzerinde kullanım alanının yaygınlaşması form sitelerinde ki ağızdan ağıza iletişimler medya araçlarında çeşitliliğin artması bilgiye ulaşımın kolaylaşması müşterilerin bu kanallara yönelmesini sağlayarak iletişim boyutunu en önemli faktörlerden birisi haline getirdiğini söyleyebiliriz. Sosyal sorumluluk boyutu etkisinin diğerlerine göre daha düşük çıkmasını değerlendirdiğimizde ise kurumun müşterilerine doğrudan sağlayacağı bireysel kazanımların, toplumsal fayda ile dolaylı olarak sağlayacağı yararlardan daha fazla önemsediği sonucunu çıkartabiliriz.

Bu doğrultuda sağlık kuruluşlarının toplum üzerinde olumlu imaj yaratacak dizaynı gerçekleştirebilmeleri amacıyla kurumun fiziksel unsurlarında sürekli iyileştirmeler yapması ve çağın dinamiklerine uygun hale getirmesi gerekmektedir.

Aynı zamanda iletişim faktörünü destekleyecek şekilde sponsorluk, reklam, pazarlama halkla ilişkileri vb. iç ve dış iletişim faaliyetleri yürütülmelidir.

Hizmetin üretim sürecinde, kalite yönetim sistemi, ahlaki bir felsefe olarak görülmelidir. Bunun sonucu olarak süreçleri iyileştirmeli, hatalar ortadan kaldırılmalı, israfı azaltılmalı, kalite yönetim sistemleri içerisinde geçerliliği ispatlanmış kalite iyileştirme ve problem çözme araçları kullanılmalıdır. Bu sayede kurumlar kalite yönetimi faaliyetleri içerisinde günümüzde önemi giderek artan akredite olabilecek standartları sağlama yolunda da kolaylık elde edilebilirler. Müşterilerin istek ve ihtiyaçlarının karşılanması suretiyle tatmin duygusu oluşturacak hizmetin sunumu da gerçekleşebilecektir. Bu durum da iç diş ve global müşterilere, kurumsal imajın olumlu yansımasını sağlayacaktır.

Bunlara ek olarak toplum ile birlikte yaşayan faaliyetlerini sürdüren sağlık kuruluşları, topluma karşı mesuliyetlerini yerine getirerek kendilerinin dişındaki birey ve kurumlarla ilişkilerini güçlendirmeli çalışanlarından tüketicilerine saygı duyulan ve güvenilen kurumlar olarak tanımlanabilirler. Bunu da sosyal sorumluluk bilinci ile yapabilirler.

Araştırmada yaş değişkeni açısından sonuçlara bakıldığında kurumsal imaj açısından farklılık tespit edilmemiştir. Algılanan imajda ise farklılık olduğu görülmektedir. En yüksek imaj algısı 25 yaş ve altında gerçekleşmiştir. Bu grubun hastaneye ilişkin algılarının diğer yaş gruplarına göre daha olumlu olduğu görülmektedir.

Y kuşağı sonu ve Z kuşağı olarak tarif edilen bu gençlerin sunulan mal ya da hizmetin kişiselleştirilmiş olmasını önemsediği ve kendine has imaja dayanan ürünlere yöneldiği bilinmektedir. Bu kuşak mal ya da hizmetleri tercih etmeden önce, alternatifler arasında dijital ortam da araştırma yapmaktadırlar. Bu kuşağın üyeleri almış oldukları mal ya da hizmetleri kendilerine özgü olarak yeniden şekillendirirler ve görüşlerini dijital platformlarda sıklıkla dile getirirler. Bu kuşak tüketim alışkanlıklarında yaratıcılı̆̆ 1 ve bilinçli satın almayı kendisinden önceki kuşaklardan daha fazla önemseyen bir kuşaktır (Gümüş, 2020). Dolaysıyla özel hastane yöneticileri algılanan imaja yönelik pekiştirme çalışmalarını yürütürken her bir yaş aralığının beklentilerini karşılayacak şekilde stratejik araçları kullanması yerinde olacaktır.

\section{Gelecek çalışmalara öneriler}

- Günümüzün dinamik tüketici davranışlarına yönelik olarak kurumsal imaj yönetimi konusunda pazarlamacılara yol gösterici olabilmesi amacıyla literatürde kurumsal İmajın iş tatmini, örgütsel aidiyet, örgüt kültürü vb değişkenler ile ilişkisinin incelendiği çok sayıda çalışmaya rastlamak mümkündür (Google Akademik). Fakat değişen dünyanın dinamiklerine uyum ve katkı sağlamak amacıyla Endüstri 4.00 ile üretim hayatında artan dijital dönüşüm ve yapay zeka uygulamalarının yarattığı değişimin neden olduğu değişkenler, her sektör için ayrı ayrı ortaya konularak kurumsal imaj çalışmalarına dahil edilmeli ve sonuçlar yurt dışı çalışmaları ile kıyaslanmalıdır. Aynı katılımcılar üzerinden birden fazla kurumsal 
K. G. Yilmaz - E. Saygin - M. Tolon 13/3 (2021) 2780-2799

imaj ölçeği ile elde edilen veriler ve çıkan sonuçlar kıyaslanarak ölçeklerin hangisinin sağlık sektöründe daha gerçekçi etkin ve etkili sonuçlar ortaya çıaracağı araştırılmalıdır.

- Sektörel anlamda özelleştirilmiş imaj faktörlerini barındıran ölçekleri ortaya çıkarabilecek çalışmalar yapılmalıdır.

- Sağlık sektöründe kurumsal imaj çalışmalarının ve bu çalışmalarda kullanılan ölçeklerin yapısal incelemelerinin de yapılması ile birlikte çıkan sonuçların farklı araştırmacılar ile birlikte farklı yorumlarının güncel derlemeleri, sonrasında gelecek çalışmaların yönlendiriciliği açısından ele alınmalıdır.

- Hem özel hem de devlet hastanelerini kapsayacak şekilde farklı bölgelerden veriler toplanarak, farklılıkları ve değişimleri ortaya koyabilecek sosyolojik ve kültürel değişkenlere göre analizlerin yapıldığı çalışmaların artması; sağlık sektörü yöneticilerinin yeteneklerinin artırması, heterojen müşteri algılarının anlaşılması ve homojen hale getirilmesi bakımından önem taşımaktadır.

\section{KAYNAKÇA}

Adah, S. M. (2020). Effect of Corporate Image on Customer Loyalty of Selected Brewed Products in NigeriaSeminar I. ISSN 2536-7617ISSN, 76.

Adams, K., Snyder, J., Crooks, V. A., Johnston, R. (2013). Promoting social responsibility amongst health care users: medical tourists' perspectives on an information sheet regarding ethical concerns in medical tourism. Philosophy, Ethics, and Humanities in Medicine, 8(1), 19.

Aksoy, R., Bayramoğlu, V. (2008). Sağlık işletmeleri için kurumsal imajın temel belirleyicileri: Tüketici değerlemeleri. Uluslararası Yönetim İktisat ve İşletme Dergisi, 4(7), 85-96.

Aktan, C. C., Börü, D. (2007). Kurumsal sosyal sorumluluk. Kurumsal sosyal sorumluluk: İşletmeler ve sosyal sorumluluk, İGIAD Yayincilı 11-36..

Aktepe C. ve Baş M. (2008) “Marka Bilgisi Sürecinde Marka Farkındalığı ve Algılanan Kalite (Beklenti) İlişkisi ve GSM Sektörüne Yönelik Bir Analiz", Gazi Üniversitesi İ̈BF Dergisi, 10(1), 81-96.

Aktepe C. (2013) “Sağlık Turizminde Yeni Fırsatlar ve Türkiye’de Yerleşik Sağlık İşletmelerinin Pazarlama Çabaları", Journal of Business Research, 5(1), 170-188.

Anderson, E. W., Sullivan, M. W. (1990). Customer satisfaction and retention across firms, In TIMS College of Marketing Special Interest Conference on Services Marketing, Nashville, TN, September.

Aras, E. (2019). Spor örgütünde kurumsal imaj ile kurumsal itibar algısı arasındaki ilişki (Spor İstanbul örneği). Yüksek Lisans Tezi, İstanbul Gelişim Üniversitesi Sağllk Bilimleri Enstitüsü, İstanbul. 2019

Ayten, A., Zağlı, K. (2019) Kamu Ve Özel Hastane Ayrımında Sağlık İletişiminin Hastane Kurum İmajı Algısına Etkisi Üzerine Karşılaştırmalı Bir Çalışma. İletiş̧im Çalışmaları Dergisi, 5(2), 101-126.

Başar, D., Dikmen, F. H., Öztürk, S. (2021). The prevalence and determinants of unmet health care needs in Turkey. Health Policy, 125(6), 786-792.

Bal, M. (2012). Çalışan personelin kurumsal imaj oluşumuna etkisi. Kahramanmaraş Sütçü İmam Üniversitesi Íktisadi ve İdari Bilimler Fakültesi Dergisi, 2(1), 219.

Başol, E. (2018). Hasta ile Sağlık Çalışanları (Doktor ve Hemşire) Arasındaki İletişim Sorunları ve Çözüm Önerileri. International Anatolia Academic Online Journal/Social Science Journal, 4(1), 76-93.

Bayın, G., Akbulut, Y. (2012). Sağlık sektöründe sosyal pazarlamanın kullanımı. Ankara Sağlık Bilimleri Dergisi, 1(1), 53-72.

Bayın, G., Önder, Ö. R. (2014). Sağlık kurumlarında imaj üzerine bir araştırma. Mustafa Kemal Üniversitesi Sosyal Bilimler Enstitüsü Dergisi, 11(27), 141-158.

Bayramoğlu, V. (2007). Sağlık işletmeleri için kurumsal imajın temel belirleyicileri: Zonguldak örneği. Yayımlanmamış yüksek lisans tezi. Zonguldak Karaelmas Üniversitesi, Zonguldak, Türkiye. 
K. G. Yilmaz - E. Saygin - M. Tolon 13/3 (2021) 2780-2799

Brandão, C., Rego, G., Duarte, I., Nunes, R. (2013). Social responsibility: a new paradigm of hospital governance?. Health Care Analysis, 21(4), 390-402.

Creixans-Tenas, J., Coenders, G., Arimany-Serrat, N. (2019). Corporate social responsibility and financial profile of Spanish private hospitals. Heliyon, 5(10), e02623.

Çalışır, Z. (2019) Kurumsal Sosyal Sorumluluk Ve Kurumsal İmaj Arasındaki İlişki: Bir Alan Araştırması. Yüksek Lisans Tezi, Kahramanmaraş Sütçü İmam Üniversitesi, Kahramanmaraş. 2019

Çatı, K., Baydaş, A. (2008). Hizmet Pazarlaması ve Hizmet Kalitesi. Asil Yayınları, Ankara.

Çerik, Ş., Erkmen, T. (2006). Kurum imajını etkileyen faktörlerin algılanması ve bu algılamaların beklentilerle karşılaştırılması: üniversite öğrencilerine yönelik bir araştırma. Mustafa Kemal Üniversitesi Sosyal Bilimler Enstitüsü Dergisi, 3(6).

Çetin, S., Tekiner, M. A. (2015). Kurumsal İmajın Temel Belirleyicileri: Emniyet Teşkilatı Örneklemi İç Paydaş Anketi. Yönetim ve Ekonomi Araştırmaları Dergisi, 13(1), 418-440.

Çiçek, B., Almalı, V. (2020). Kurumsal Kimlik Oluşturmada Kurumsal İmaj Algısının Rolü: Örgüt Kültürünün Aracılık Etkisi. Yönetim ve Ekonomi: Celal Bayar Üniversitesi İktisadi ve İdari Bilimler Fakültesi Dergisi, 27(2), 219-238.

Deniz, S., Yüksel, O. (2019) Sağlık Tüketicilerinin Kurumsal İmaj Algısı İle Hastane Bağlılığı Arasındaki İlişkinin Belirlenmesine Yönelik Bir Araştırma. Avrasya Uluslararası Araştırmalar Dergisi, 6(15), 927-934.

Derin, N., Demirel, E. T. (2010). Kurum İmajının Kurum Kimliği Açısından Açılanabilirliği: İnönü Üniversitesi Turgut Özal Tıp Merkezi Örneği. Hacettepe Să̆lık İdaresi Dergisi, 13(2), 155-193.

Dikmen, D. B., Dikmen, F. H. (2020). Türkiye'de Karşılanamayan Ağız Ve Diş Sağlığı Bakım İhtiyaçlarını Etkileyen Sosyo-Ekonomik Faktörlerin Analizi. Hacettepe Sağllk İdaresi Dergisi, 23(4), 537-546.

Emül, B., Naldöken, Ü. (2019) Sağlık Kurumlarında Kurumsal İmajın Hasta Memnuniyetine Etkileri. Hacettepe Sağllk İdaresi Dergisi, 22(2), 359-374.

Erbaydar, T. (2003). Halk sağlığı açısından sağlık iletişimi. CÜ Tıp Fakültesi Dergisi, 25(4), 45-51.

Erdoğan, B. Z., Develioğlu, K., Gönüllüoğlu, S., \& Özkaya, H. (2006). Kurumsal imajin şirketin farklı paydaşları tarafından algılanışı üzerine bir araştırma. Dumlupınar Üniversitesi Sosyal Bilimler Dergisi, 15, 55-76.

Erdoğan, Z. (2014). Pazarlama ilkeler ve yönetim. Bursa: Ekin Yayınevi.

Erkan, M. (2014). Kurumsal İmajın Güçlendirilmesinde Kurumsal Kimliğin Rolü. Yüksek Lisans Tezi, Ege Üniversitesi, Sosyal Bilimler Enstitüsü, İzmir.

Furman, D. M. (2010). The development of corporate image: A historiographic approach to a marketing concept. Corporate Reputation Review, 13(1), 63-75.

Ghobadian, A., Speller, S., Jones, M. (1994). . Service quality: concepts and models. International journal of quality $\mathcal{E}$ reliability management.

Gray, E. R., Balmer, J. M. (1998). Managing corporate image and corporate reputation. Long range planning, 31(5), 695-702.

Grönroos, C. (1990). Service management and marketing (Vol. 223). Lexington, MA: Lexington books.

Gümüş, N. (2020). Z kuşağı tüketicilerin satın alma karar tarzlarının incelenmesi. Journal of Yaşar University, 15(58), 381-396.

Gümüş, S., Göker, E. Ü. (2012). Hizmet Kalitesinin Hizmet Performansına Etkisi: Bir Hastane Uygulama (1. Baskı). İstanbul: Hiberlink Yayınları 
K. G. Yilmaz - E. Saygin - M. Tolon 13/3 (2021) 2780-2799

Güngör, T., Şahin, A. O., Bayram, S. S. (2020) Sağlık Kurumlarında Kurumsal İmaj Algısı ve Örgütsel Bağl1lık Arasındaki İlişki. Sağllk ve Hemşirelik Yönetimi Dergisi

Gülen, G. (2019) Kurumsal İletişim Perspektifinden Güçlü Bir Kurumsal İmajın Oluşturulmasında Çalışan Motivasyonunun Önemi. Yüksek Lisans Tezi, Ege Üniversitesi, İzmir. 2019

Hoşgör, H., Memiş, K., Gündüz Hoşgör, D., Koç Tütüncü, S. (2017). Kurumsal hastane imajı, algılanan fiyat uygunluğu, hasta tatmini ve sadakati arasındaki ilişkilerin yapısal eşitlik modeliyle incelenmesi. International Journal of Academic Value Studies

Ishaq, I. M. (2012). Perceived value, service quality, corporate image and customer loyalty: Empirical assessment from Pakistan. Serbian Journal of Management, 7(1), 25-36.

Kanoğlu, F. (2016) Kurum İmajının Müşteri Memnuniyetine Etkisi: Kamu-Özel Hastane. Yüksek Lisans Tezi, Düzce Üniversitesi, Düzce. 2016

Karakaya, A., Kılıç, İ., Uçar, M. (2016). Üniversite öğrencilerinin öğretim kalitesi algısı üzerine bir araştırma. Karabük Üniversitesi Sosyal Bilimler Enstitüsü Dergisi, Özel, 2, 40-55.

Kavuncubaşı, Ş., Yıldırım, S. (2015). Hastane Ve Sağlık Kurumları Yönetimi (4. Baskı). Ankara: Siyasal Kitabevi

Kaya S. [Editör] (2014). Sağlık Kurumlarında Kalite Yönetimi. Üçüncü Baskı, Anadolu Üniversitesi Yayınları, Eskişehir [Yazarlar: Sıdıka Kaya, Dilaver Tengilimoğlu, Oğuz Işık, Mahmut Akbolat Ve Ali Yılmaz].

Kayral, İ. H. (2015). Hizmet Kalitesi Ve Sağlık Hizmetlerinde Çok Boyutlu Kalite (1.Baskı). Ankara: Detay Yayıncilık

Koç, E. (2017). Hizmet Pazarlaması Ve Yönetimi (2.Baskı). Ankara: Seçkin Yayıncılık

Matová, H., Dzian, M., Triznová, M., Paluš, H., \& Parobek, J. (2015). Corporate image profile. Procedia Economics and Finance, 34, 225-230.

McAlexander, J. H., Kaldenberg, D. O., \& Koenig, H. F. (1994). Service quality measurement. Journal of health care marketing, 14(3), 34-40.

Önder, Ö. R., Bayın, G. (2014). Poliklinik ve klinik hastalarının kurum imajı ve hasta bağlılığı algılarının karşılaştırılması: Ankara'da bir eğitim ve araştırma hastanesi örneği. İşletme Araştırmaları Dergisi, 6(4), 120-138.

Özata, M., Sevinç, İ. (2007). Hastanelerde kurumsal imajın ölçülmesinde dikkate alınması gereken faktörlerin belirlenmesi. Journal of Azerbaijani Studies

Özdemir, Ö. Ü. O., Akay, Y. (2021). Ekonomisi, İ., Finans, A. B. D. Kurumsal Kültürün Kurumsal İmaja Etkisi: Şırnak Emniyet Müdürlüğü Üzerine Bir Araştırma. In Internatıonal Academıcıan Studıes Congress 2021 Sprıng/Proceedıngs Book (p. 65). Rating Academy Ar-Ge Yazılım Yayıncllık Eğitim Danışmanlık ve Organizasyon Ticaret Limited Şirketi.

Özer, G. (2020) Örgüt Kültürünün Kurumsal İmaj Ve Örgütsel Bağlllı̆̆a Etkisi. Yüksek Lisans Tezi, Bahçeşehir Üniversitesi, İstanbul. 2020

Parasuraman, A., Berry, L. L., Zeithaml, V. A. (1993). Research note: More on improving quality measurement. Journal of retailing, 69(1), 140.

Parish, J. T., Berry, L. L., Lam, S. Y. (2008). The effect of the servicescape on service workers. Journal of Service Research, 10(3), 220-238.

Resnik, D. B. (2007). Responsibility for health: personal, social, and environmental. Journal of medical ethics, $33(8), 444-445$.

Rose, S. (1990). The coming revolution in credit cards. Journal of Retail Banking, 12(2), 17-19. 
K. G. Y1lmaz - E. Saygin - M. Tolon 13/3 (2021) 2780-2799

Semerci, N. (2016). Sağllk İşletmelerinde Kurumsal İmajı Belirleyen Faktörler. Journal of Strategic Research in Social Science, 2(2), 17-38.

Shee, P. S. B., Abratt, R. (1989). A new approach to the corporate image management process. Journal of marketing management, 5(1), 63-76.

Somunoğlu, S., Erdoğan, M. C., Özer, P. (2013). Sağllk sektöründe halkla ilişkiler ve iletişim uygulamalarına genel bir bakış. İnönü Üniversitesi Sağlık Hizmetleri Meslek Yüksek Okulu Dergisi, 1(1), 6-12.

Süer, İ. (2014). Pazarlama İlkeleri. (1.Bask1 ). Ankara: Nobel Akademik Yayıncılık.

Sümbüloğlu, K., Biyoistatistik, S. V. (1998). Hatiboğlu Yayınevi. Baskı, Ankara, 264-265.

Takahashi, T., Ellen, M., Brown, A. (2013). Corporate social responsibility and hospitals: US theory, Japanese experiences, and lessons for other countries. In Healthcare management forum (Vol. 26, No. 4, pp. 176-179). Sage CA: Los Angeles, CA: SAGE Publications.

Taşçı, D. Ç., Nihan, S. (2013). Kalite Yönetim Sistemleri. Anadolu Üniversitesi Açıköğretim Fakültesi Yayını, Eskişehir.

Taşdemir, R., Oğuzöncül, A. F., Bengü Durmuş, B. (2015). Hastaneleri Fiziki Yapısının Yatan Hastaların Memnuniyet Düzeyleri Üzerine Etkisi. Sağllkta Performans ve Kalite Dergisi,(10), 1-12.

Taşkın, E., Sönmez, S. (2005). Kurumsal imaj oluşturmada halkla ilişkilerin rolü ve bir alan araştırması. Akademik Bakış Uluslararası Hakemli Sosyal Bilimler E-Dergisi, 7, 1-27.

Tengilimoğlu, D. (2016) Sağlık Hizmetleri Pazarlaması (4. Baskı). Ankara: Siyasal Yayın Dağıtım

Tunçel, M., Doğan, Ö. V., Çobaner, A. A. (2012). Performans Sistemine Medyanın Bakışını Anlamak: Performans Konulu Sağlık Haberleri Üzerine Bir Araştırma. Sağlıkta Performans ve Kalite Dergisi, 3(1), 93-118.

Turancl, E., Bulut, S. (2016). Neo-Liberalizm Ve Sağllk Hizmetlerinin Dönüşümü: Özel Să̆glı Sektörünün İletişim Politikalar Üzerine Bir Analiz. İletişim Kuram Ve Araştırma Dergisi, (43).

Uluçay, D. M. (2018). Üniversitelerde Kurumsal İmaj Ölçümü. Dumlupınar Üniversitesi Sosyal Bilimler Dergisi, (55), 17-36.

Ural, E. G. (2000). Kurum imajı yaratmada sosyal sorumluluk anlayışının önemi. İstanbul Üniversitesi İletişim Fakültesi Dergisi, 10, 411-419.

Virvilaite, R., Daubaraite, U. (2011). Corporate social responsibility in forming corporate image. Engineering Economics, 22(5), 534-543.

Woodside, A. G., Frey, L. L., Daly, R. T. (1989). Linking sort/ice anlity, customer satisfaction, and behavioral intention. Journal of health care marketing, 9(4), 5-17.

Yeşiltaş, A., Erdem, R. (2017). Hastanelerin kurumsal sosyal sorumluluk faaliyetlerine yönelik içerik analizi. Mersin Üniversitesi Sağlık Bilimleri Dergisi, 10(2), 113-124.

Zeithaml, V. A., Berry, L. L., Parasuraman, A. (1988). Communication and control processes in the delivery of service quality. Journal of marketing, 52(2), 35-48. 